\title{
PREPARO E CARACTERIZAÇÃO FÍSICO-QUÍMICA E BIOLÓGICA DE UM BIOCOMPÓSITO À BASE DE CELULOSE ASSOCIADA À PRÓPOLIS
}

Dissertação de mestrado apresentada ao Programa de Pós-Graduação Interunidades em Bioengenharia - Escola de Engenharia de São Carlos, Faculdade de Medicina de Ribeirão Preto e Instituto de Química de São Carlos da Universidade de São Paulo como parte dos requisitos para a obtenção do título de mestre em Ciências.

Área de Concentração: Bioengenharia Orientadora: Prof. Dra. Ana Maria Minarelli Gaspar 
AUTORIZO A REPRODUÇÃO E DIVULGAC̄ÃO TOTAL OU PARCIAL DESTE TRABALHO, POR QUALQUER MEIO CONVENCIONAL OU ELETRÓNICO, PARA FINS DE ESTUDO E PESQUISA, DESDE QUE CITADA A FONTE.

\section{Ficha catalográfica preparada pela Seçăo de Tratamento} da Informaçáa do Serviço de Biblioteca - EESC/USP

\begin{tabular}{|c|c|}
\hline P592p & $\begin{array}{l}\text { Picchi, Juliano Bottura } \\
\text { Preparo e caractorizaço físico-química e biológica de } \\
\text { um biocompósito á base de celulose associada á própolis } \\
\text { Juliano Bottura Picchik; orientador Ana Maria Minarelli } \\
\text { Gaspar. - - São Carlos, } 2010 \text {. }\end{array}$ \\
\hline & $\begin{array}{l}\text { Dissertação (Mestrado--Prograna de Pós-Graduação e Area } \\
\text { de Concentraça Interunidades em Bioengenharia)-- Escola } \\
\text { de Engenharia de São Carlos, Faculdade de Medicina de } \\
\text { Ribeirão Preto e Instituto de Química de São Carlos da } \\
\text { Universidade de São Paulo, } 2010 \text {. }\end{array}$ \\
\hline & $\begin{array}{l}\text { 1. Materiais compósitos. 2. Membrana de celulose, } 3 . \\
\text { Própolis. 3. Biocompósito. Título. }\end{array}$ \\
\hline
\end{tabular}


JULIANO BOTURA PICCHI

MESTRADO EM CIÊNCIAS

ÁREA DE BIOENGENHARIA

DISSERTAÇÃO APRESENTADA AO PROGRAMA DE POS - GRADUAÇÃO INTERUNIDADES BIOENGENHARIA EESC - FMRP - IQSC DA UNIVERSIDADE DE SÄO PAULO PARA OBTENÇÃO DO TITTULO DE MESTRE EM CIEENCIAS NA ÁREA DE BIOENGENHARIA.

Aprovado em:21/12/2010

PROFA. DRA. ANA MARIA MINARELLI GASPAR (ORIENTADORA)

Universidade Estadual Paulista "Júlio de

Resultado: APROJADN

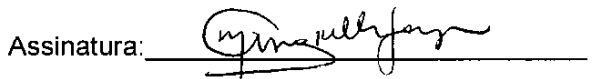

PROF. DR. YOUNES MESSADDEQ Universidade Estadual Paulista "Júlio de
Mesquita Filho"

Resultado: Aprovalo

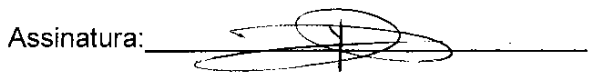

PROF. DR. TICIANA SIDORENKO DE OLIVEIRA CAPOTE

Universidade Estadual Paulista "Júlio de

Resultado: Amovado Mesquita Filho"

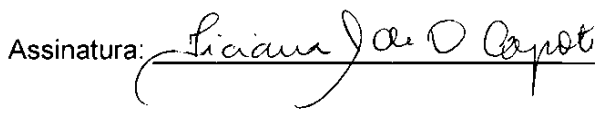

A1. Trubalhador Säo-carlense, 400-Centro-São Carlos - SP - $13566-590$ 
Dedico este trabalho:

Em primeiro lugar à Deus que foi meu grande apoio durante toda a minha vida em todos os momentos.

Aos meus pais Olga e José Emilio e aos meus irmãos Carla e Mateus que sempre estiveram ao meu lado dando-me apoio, carinho e força para conseguir vencer as dificuldades e saudades, agradeço à Deus todos os dias por vocês existirem.

Em especial minha esposa Bianca e minha filhinha Maria Clara que sempre me apoiaram no que foi preciso para a minha formação e na minha profissão, estando sempre ao meu lado, me proporcionando felicidade, alento e carinho em todos os momentos da minha vida. Deus os abençõe!!

Obrigado a todos!!!!! 
Agradecimentos:

Agradeço especialmente ao Professor Doutor Younès Messadeq pela oportunidade, pela possibilidade de expansão de meus horizontes de conhecimento e pela dedicação durante a realização deste trabalho.

Ao Professor Doutor Sidney José Lima Ribeiro pelo apoio e contribuições importantes para a realização desse trabalho.

Ao Dr. Hernane Barud, do Departamento de Química Inorgânica do Instituto de Química da UNESP, pelo auxílio e grande colaboração na confecção deste trabalho.

Ao meu colega e amigo, Danillo, que sempre esteve ao meu lado no trabalho e estudos com incentivo e apoio.

Em especial, meu agradecimento para a minha orientadora Prof. Dra. Ana Maria Minarelli Gaspar, pela paciência, incentivo e dedicação.

À toda minha família e amigos que fazem parte importante do meu ser.

Enfim, muito obrigado a TODOS que de uma forma ou de outra contribuíram para a realização deste trabalho e para a minha formação como ser humano. 
“Ante os portais da excelência os deuses mais poderosos depuseram o seu suor. Longo é o caminho que até ali conduz, ingrime e acidentado no começo. Mas, quando o alto é atingido, encontra-se a tranqüilidade - embora ganha com muito suor”.

HESIODO - Trabalhos e Dias 


\section{Sumário}

RESUMO

ABSTRACT

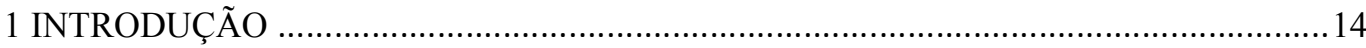

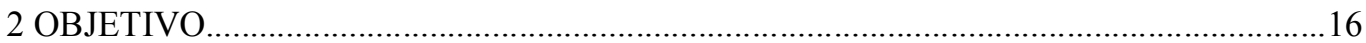

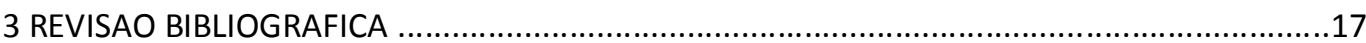

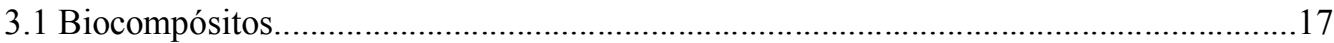

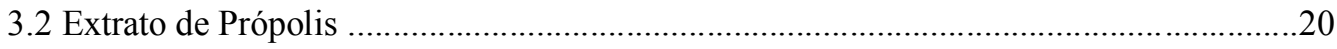

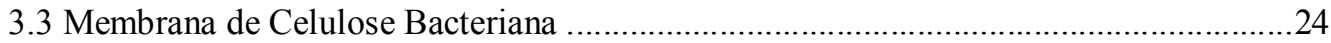

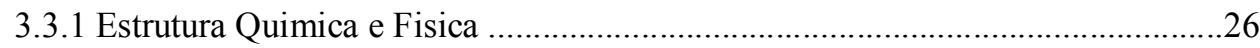

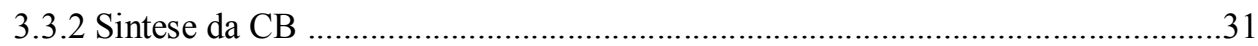

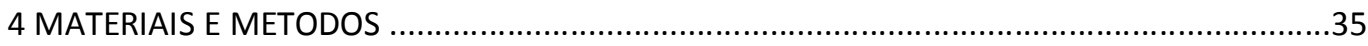

4.1 Preparação das membranas de celulose bacteriana ...........................................35

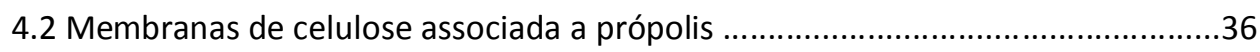

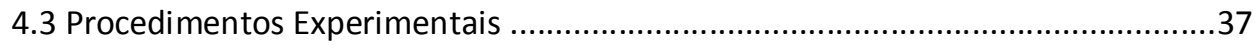

4.3.1 Caracterizacao Fisico-Quimica e Morfologica das CBP ....................................37

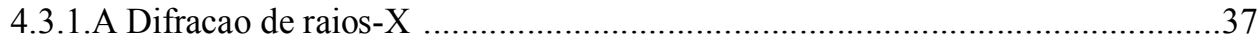

4.3.1.B Espectroscopia Vibracional de Absorcao na Regiao do Infravermelho ...........37

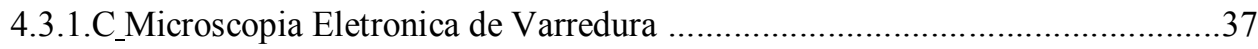

4.3.1.D Termogravimetria e Analise Termica Diferencial ...........................................38

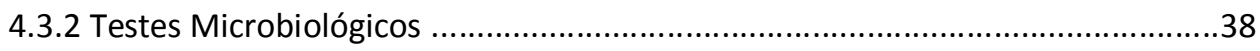

4.3.2.A Padronização do método da macrodiluição para determinação da atividade

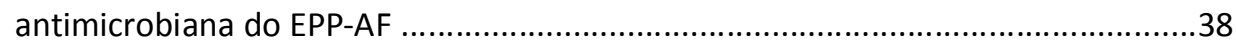

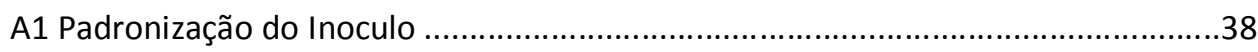

A2 Padronização do Método da Macrodiluicao ........................................................39 


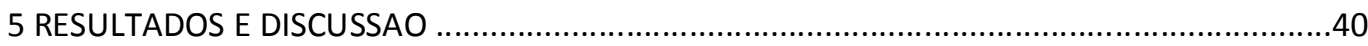

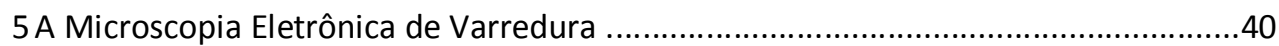

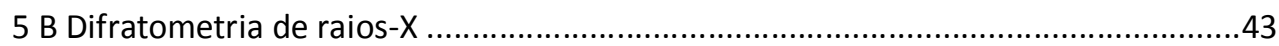

5 C Espectroscopia Vibracional na Região de Infravermelho .....................................45

5 D Analise Termogravimétrica e Calorimetria Exploratória Diferencial .......................46

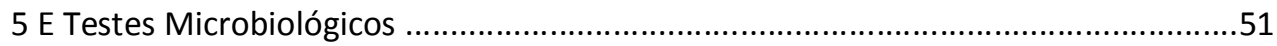

5.E.1 Avaliação da Atividade Antimicrobiana de Membranas contendo Extrato

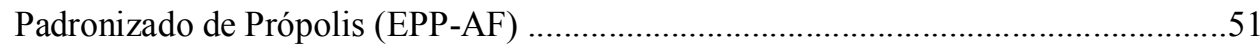

5.E.2 Comparação do método da macrodiluição com o método da difusão em Agar para determinação da atividade antimicrobiana do EPP-AF ........................................57

5.E.a Avaliação da atividade antimicrobiana do EPP-AF .............................................58

5.E.b Avaliação da atividade antimicrobiana da membrana ........................................59

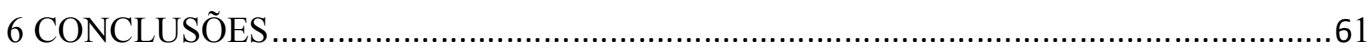

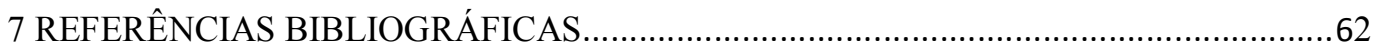




\section{INDICE DE FIGURAS}

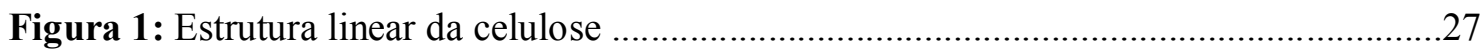

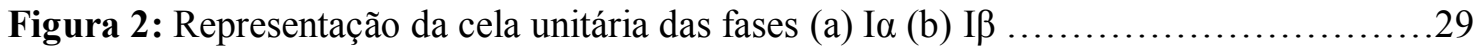

Figura 3: Microscopia eletrônica de varredura da $\mathrm{CB}$ a) Em destaque a bactéria A. Xilinum;

b) As microfibras de celulose podem ser claramente observadas 31

Figura 4: Micrografia eletrônica de transmissão da bactéria A. xylinum durante a produção de celulose .32

Figura 5: Micrografia eletrônica de varredura da rede de celulose incluindo as células

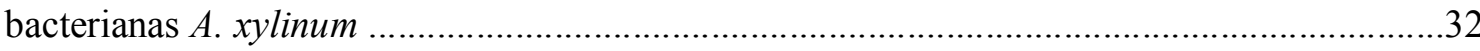

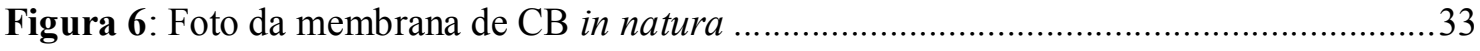

Figura 7: (A) Micrografia eletrônica de varredura da CB seca; (B) modelo das microfibrilas hidratadas da celulose bacteriana 33

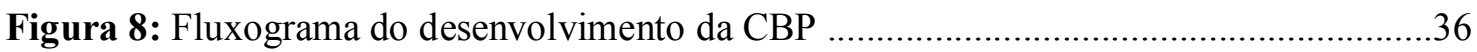

Figura 9: Microscopia Eletrônica de Varredura CB-própolis .............................................41

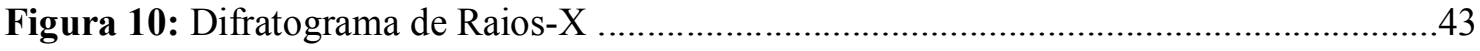

Figura 11: Espectroscopia Vibracional na Região do Infravermelho ...................................45

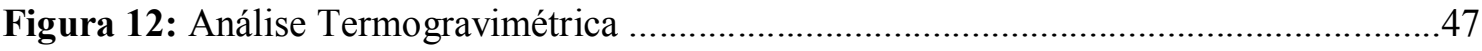

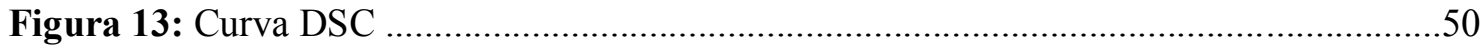

Figura 14: Atividade antimicrobiana do EPP-AF frente ao S. aureus ATCC 25923 por meio do método da macrodiluição .53

Figura 15: Atividade antimicrobiana das membranas contendo EPP-AF frente a (a) S. aureus ATCC 25923, (b) S. aureus (MRSA) ATCC 43300. 58

Figura 16: Atividade antimicrobiana das membranas contendo EPP-AF frente a S. aureus ATCC 25923 e $S$. aureus (MRSA) ATCC 43300 


\section{ÍNDICE DE TABELAS}

Tabela 1: Composição do meio de cultura ………………………………………………....35

Tabela 2: Medidas de espessura e rugosidade para CB e membranas CBP............................42

Tabela 3: Absorbância das suspensões e número de S. aureus ATCC 25923 obtido nos ensaios para a padronização do inoculo inicial .....................................................................51

Tabela 4: Absorbância das suspensões e número de S. aureus ATCC 25923 obtido nos ensaios para a padronização do inoculo final .....................................................................52

Tabela 5: Atividade antimicrobiana (Concentração Bactericida Mínima - CBM) do extrato padronizado de própolis (EPP-AF) frente ao S. aureus ATCC 25923, utilizando o método da

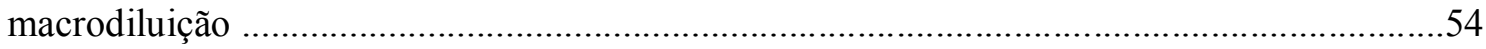

Tabela 6: Atividade antimicrobiana (Concentração Bactericida Mínima - CBM) do extrato padronizado de própolis (EPP-AF) frente ao $S$. aureus ATCC 25923, utilizando o método da difusão em Agar .55

Tabela 7: Atividade antimicrobiana do extrato padronizado de própolis (EPP-AF) utilizando o método da difusão em Agar.

Tabela 8: Atividade antimicrobiana das membranas contendo extrato padronizado de própolis (EPP-AF) em diferentes concentrações, por meio do método da difusão em Agar 60 


\section{ÍNDICE DE ABREVIATURAS}

ASTM - AMERICAN SOCIETY FOR TESTING AND MATERIALS

$\mathrm{CB}$ - celulose bacteriana

CBP - membrana de celulose bacteriana com própolis

CBS - membrana de celulose bacteriana seca

$\mathrm{CBH}$ - membrana de celulose bacteriana hidratada

$\mathrm{CV}-$ celulose vegetal

CIM - concentração inibitória mínima

CBM - concentração bactericida mínima

CLSI - National Committee for Clinical Laboratory Standards

CAPE - ester fenetilacido cafeico

COX-1 - ciclooxigenase-1

COX-2 - ciclooxigenase-2

DTA - analise térmica diferencial

DRX - difratometria de raios-X na região do infravermelho

DSC - calorimetria exploratória diferencial

EPP-AF - extrato padronizado de própolis

FTIR - espectroscopia vibracional

HIV - vírus da imunodeficiência humana

MEV - microscopia eletrônica de varredura

PU - resina de poliuretano

$\mathrm{TG}$ - termogravimétrica 
TGA - análise termogravimétrica

UFC - unidade formadora de colônias 


\section{RESUMO}

PICCHI, J. P. (2010). Preparo e caracterização físico-química de um biocompósito `a base de celulose associada `a própolis. $71 \mathrm{f}$. Dissertação (Mestrado) - Programa de PósGraduação Interunidades em Bioengenharia - Escola de Engenharia de São Carlos/ Faculdade de Medicina de Ribeirão Preto/ Instituto de Química de São Carlos - Universidade de São Paulo, São Carlos, 2010.

O desenvolvimento de novos materiais com fonte renovável, baixo custo, melhores propriedades físico-mecânicas e biodegradáveis tem se tornado o principal objetivo de muitas empresas e grupos de pesquisa. O objetivo deste trabalho foi preparar e caracterizar física, química e biologicamente um biocompósito à base de membrana de celulose com própolis. Foram preparadas membranas de celulose com própolis nas concentrações de $1,2 \%, 2,4 \%$ e 3,6\%, secas e úmidas, realizados testes de caracterização através de Espectroscopia Vibracional na Região Infra-Vermelho, Difratometria de Raios-X, Microscopia Eletrônica de Varredura, Análise Térmica [Calorimetria Exploratória Diferencial e Termogravimetria] e análise microbiológica para $S$. aureus. A presença de concentrações diferentes de própolis nas membranas foi identificada nos diversos métodos utilizados e através do ensaio antimicrobiano, a concentração mínima de $0,34 \%$ de própolis foi ativo à $S$. aureus. Portanto, os resultados obtidos são promissores para trabalhos futuros in vivo e possíveis aplicações médicas.

Palavras chaves: celulose, própolis, compósitos. 


\begin{abstract}
PICCHI, J. B. (2010). Preparation and physicochemical and biological characterization of a based cellulose biocomposite associated with propolis. $71 \mathrm{f}$. Dissertação (Mestrado) Programa de Pós-Graduação Interunidades em Bioengenharia - Escola de Engenharia de São Carlos/ Faculdade de Medicina de Ribeirão Preto/ Instituto de Química de São Carlos Universidade de São Paulo, São Carlos, 2010.
\end{abstract}

The development of new materials with renewable, low cost, better physical and mechanical properties and biodegradable has become the main goal of many companies and research groups. The aim of this work was to prepare and characterize physical, chemical and biologically biocomposites based in a cellulose membrane with propolis. Cellulose membranes were prepared with propolis at concentrations of $1.2 \%, 2.4 \%$ and $3.6 \%$, wet and dry tests performed characterization using vibrational spectroscopy Infra-Red, X-ray Diffraction, Microscopy Scanning Electron, thermal analysis [differential scanning calorimetry and thermogravimetric] and microbiological analysis for S. aureus. The presence of different concentrations of propolis in the membranes was identified in various methods used by testing and antimicrobial, the minimum concentration of $0.34 \%$ propolis was active at St. aureus. Therefore, the results are promising for future studies in vivo and potential medical applications.

Key words: cellulose, propolis, composites. 


\section{INTRODUÇÃO}

Novos materiais com melhores propriedades físico-mecânicas, baixo custo e se possível biodegradável são obtidos por meio da formação de compósitos com fibras naturais e matriz polimérica. Esse interesse surgiu com maior intensidade no início da década de 90 devido às exigências das autoridades legislativas quanto ao uso e destino final de fibras sintéticas e resinas derivadas do petróleo e a maior conscientização dos consumidores da necessidade de preservação do ambiente e de fontes naturais segundo Klemm et al. (2005).

A fibra de celulose bacteriana produzida pela bactéria do gênero Acetobacter xylinum tem algumas características como a alta cristalinidade, resistência à tração, elasticidade, durabilidade, elevada capacidade de absorção e retenção de água, mas sua principal diferença com relação a outros tipos de celulose encontrada é o tamanho da fibra produzido pela bactéria (KLEMM, et al., 2005). Além disso, a membrana de celulose (CB) é um polímero biodegradável e biocompatível, não tóxico e não alergênico segundo Klemm et al. (2001) e consequentemente, devido a todas essas propriedades a CB torna-se um material promissor no preparo de materiais compósitos.

A produção da CB varia dependendo da cepa utilizada. Certas cepas de A. xylinum são capazes de produzir, num intervalo de 48 e 96 horas, dentro de um meio de cultura bastante simples, uma quantidade de celulose que um eucalipto levaria meses. Supõe-se que $10.000 \mathrm{~kg}$ de $\mathrm{CB}$ podem ser obtidos anualmente numa cultura estática de um hectare e somente $600 \mathrm{~kg}$ de algodão é colhido no mesmo período de tempo em uma mesma área (STEINBÜCHEL, DOI, 2005). Portanto, o grande desafio é achar a cepa produtora, pois vários grupos de pesquisa no mundo estão explorando esta fonte sem sucesso e pode-se considerar que o Brasil é o único país no mundo que conhece esta tecnologia de produção em grande escala a partir 
da cepa A. xylinum segundo Barud et al. (2007).

A própolis ganhou popularidade tanto como a medicina alternativa ou suplemento dietético para a melhora da saúde e prevenção de doenças em várias partes do mundo, incluindo Estados Unidos da América, União Européia e Japão (TEIXEIRA et al., 2005). A própolis produzida no Sudeste do Brasil é conhecida como própolis verde por causa de sua cor (MARCUCCI et al., 1998). Estudiosos do assunto atualmente recomendam seu uso, pois ela exibe atividades antibacteriana, antifúngica, antiviral, hepatoprotetora, anti-inflamatória, propriedades imunomoduladores e anti-ulcerosas (REIS et al., 2000; CASTALDO, CAPASSO, 2002).

A origem natural do compósito de celulose e própolis, o torna um produto puro e "verde", extraído diretamente da natureza sem a necessidade de adventos artificiais, o que, nos tempos atuais, contribui com a doutrina de sustentabilidade na Terra.

Associar as várias propriedades da $\mathrm{CB}$ com a própolis pode gerar um biomaterial promissor, principalmente para utilização na diferentes áreas médicas. 


\section{OBJETIVO}

O objetivo deste trabalho foi preparar e caracterizar física, química e biologicamente a membrana a base de celulose associada à própolis, em diferentes concentrações. 


\section{REVISÃO BIBLIOGRÁFICA}

\subsection{Biocompósitos}

Segundo a norma da American society for testing Materials (ASTM) 3878-95, compósito é constituído por dois ou mais materiais, insolúveis entre si, que são combinados para formar um material de engenharia útil com certas propriedades que não se encontram nos materiais isoladamente. As combinações ocorrem entre metais, cerâmicas e polímeros, estando condicionadas às condições de processamento e as prováveis incompatibilidades entre os componentes (SILVESTRE FILHO et al., 2001).

Os polímeros, por seu componente matricial, são os materiais mais utilizados devido à sua leveza e fácil moldagem. Em relação ao peso, os materiais compósitos poliméricos apresentam propriedades mecânicas específicas que podem exceder consideravelmente a dos metais. Os materiais poliméricos são divididos em duas grandes classes: termoplásticos (polipropileno, poliestireno, poliuretanos entre outros) e termorrígidos (epóxi, fenólica e poliuretano), sendo estas as classes mais utilizadas como matriz em compósitos (MATTHEWS, RAWLINGS, 1994).

Geralmente, compósitos para aplicações estruturais utilizam fibras, sintéticas ou naturais, como agentes de reforço. As fibras podem ser contínuas ou descontínuas, alinhadas ou com distribuição aleatória, podendo ser obtidas em uma variedade de formas, como mantas, fios, tiras e pré-formas têxteis, de diferentes arranjos (PAIVA, FROLLINI, 2002).

Os equipamentos necessários para se obter compósitos com estas matrizes normalmente são simples e desenvolveram-se rapidamente, sendo logo aceitos para aplicações estruturais. Compósitos poliméricos têm encontrado, por exemplo, ampla aplicação na 
indústria de construção em geral. É também de particular interesse para a indústria de construção de navios, principalmente devido a propriedades como altos módulos de resistência mecânica, o que possibilita uma significativa redução de peso na parte superior dos navios. A resistência à corrosão em ambiente marítimo é mais uma vantagem destes materiais (KUZAK, HILTZ, WAITKUS, 1998).

A utilização de compósitos poliméricos reforçados com fibras vegetais não é recente e as primeiras patentes datam da década de 60 . Durante os anos 70 e 80 , as fibras sintéticas substituíram as fibras vegetais, devido ao seu melhor desempenho e aos aspectos econômicos. Mas a partir dos anos 90 devido a aspectos ecológicos, tecnológicos e vantagens econômicas foram retomados os estudos destes materiais.

As propriedades mecânicas dos compósitos dependem de alguns fatores, tais como fração volumétrica, razão de aspecto, distribuição e orientação das fibras, adesão matriz/fibra e composição química da matriz polimérica e das fibras. A região interfacial é de fundamental importância na determinação das propriedades dos compósitos, pois é por meio da interface que os esforços atuantes na matriz são transmitidos ao reforço. Estudos relatam vários tratamentos feitos nas fibras para modificá-las e melhorar a interface, tornando-as mais compatíveis com as matrizes poliméricas, no sentido de melhorar as propriedades de adesão. (SILVA, 2003).

A obtenção de uma interface pode ocorrer por diferentes tipos de interação ou mecanismos tais como, ligação química, adesão mecânica, atração eletrostática, interdifusão entre outros (MATTHEWS, RAWLINGS, 1994). A interação entre a matriz e a fibra, pode ocorrer pelo menos por estes três mecanismos: 
- Adesão mecânica: deve haver interação entre a matriz e a fibra o suficiente para que esta resulte em interações do tipo Van der Waals. A aplicação de uma força mecânica pode tornar o mecanismo mais efetivo, favorecendo a interação entre as partes.

- Interação eletrostática: ocorre entre a matriz e o reforço quando uma superfície é carregada positivamente e a outra é carregada negativamente. As interações são eficientes em distâncias muito pequenas (distâncias atômicas) e a presença de sólidos ou gases contaminantes pode afetar sua eficiência.

- Ligação química: com relação aos compósitos, a ligação química é formada entre os grupos presentes na superfície do reforço e da matriz. Para que a interação seja mais efetiva, adiciona-se um agente de acoplamento que formará ligações hidrogênio, por exemplo, entre a matriz e o reforço (MATTHEWS, RAWLINGS, 1994).

O desenvolvimento de novos materiais compósitos a partir de fibras e polímeros de diferentes classes tem grande interesse tecnológico, porque têm características como flexibilidade, densidade baixa, dureza, resistência entre outras propriedades procuradas para os novos materiais.

A membrana de celulose bacteriana produzida pela bactéria Acetobacter xylinum é obtida na forma de uma hidrogel com características relevantes como: a alta cristalinidade, maior resistência à tração, elasticidade, durabilidade, elevada capacidade de absorção, muita retenção de água, livre de lignina e hemicelulose, quando comparada com a celulose vegetal presentes em várias fibras (KENNEDY et al., 1985; ATALLA, 1999). As fibras de celulose possuem grupos hidroxilas livres que formam ligações de hidrogênio intra e intermoleculares, característica importante para obtenção de diferentes materiais compósitos (SJOSTROOM, 1983). 
Pinto. (2007) prepararam membranas hidratadas de celulose bacteriana (CB) e resina de poliuretano (PU). Neste, o processo de troca de solvente aplicado entre a $\mathrm{CB}$ e a resina PU foi fundamental para melhorar a interface entres os precursores. Resultados obtidos por Espéctroscopia Vibracional (FTIR) revelaram a presença das principais bandas da ligação uretana e uréia dissubstituída nos biocompósitos, assim como a diminuição da banda de hidroxila $\left(3500 \mathrm{~cm}^{-1}\right)$, o que sugere uma interação entre a $\mathrm{CB}$ e os grupos NCO livres na resina. Os biocompósitos apresentaram caráter não-cristalino, e as caracterizações térmicas mostraram um aumento significativo na transição vítrea indicando um aumento no entrecruzamento da rede. Como conclusão, obtiveram biocompósitos a partir da celulose bacteriana com a resina PU utilizando o processo de troca de solvente. A caracterização do biocompósito evidenciou uma interação entre a resina PU e a fibra de CB como: i) bandas características da ligação uretana nos espectros de FTIR; ii) os bicompósitos não apresentam a cristalinidade característica da CB; iii) boa estabilidade térmica apresentada próximo a $250^{\circ} \mathrm{C}$; iv) aumento da temperatura de transição vítrea.

\subsection{Extrato de Própolis}

A própolis é uma substância fortemente adesiva, resinosa coletada, transformada e utilizada pelas abelhas para selar buracos em suas colméias, alisar as paredes internas e proteger a entrada de intrusos. As abelhas coletam a resina de rachaduras na casca das árvores e gemas. Eles trazem a própolis à colméia, onde é modificada e misturada com outras substâncias, incluindo a cera das abelhas própria e secreções salivares (GHISALBERTI, 1979).

Para a produção da própolis, as abelhas também podem usar o material ativamente secretada por plantas ou exsudados das feridas nas plantas (materiais lipofílicos nas folhas, 
mucilagens, gomas, resinas, treliças, etc.) Uma vez recolhido, o material é enriquecido com saliva e secreções enzimáticas e é usada pelas abelhas para cobrir as paredes da colméia, preencher lacunas e fissuras ou embalsamar insetos mortos invasores (CASTALDO, CAPASSO, 2002).

A própolis é um remédio natural que tem sido empregado extensivamente desde os tempos antigos; Egípcios conheciam muito bem as propriedades anti-putrefação de própolis que era usado para embalsamar cadáveres e foram reconhecidas suas propriedades medicinais por médicos gregos e romanos como Aristóteles, Dioscórides, Plínio e Galeno. A própolis foi utilizada como um anti-séptico e cicatrizante no tratamento de feridas e desinfetante bucal, sendo seu uso perpetuado na Idade Média e entre os médicos árabes; incas utilizavam a própolis como agente anti-pirético, e entre os séculos XVII e XX, a própolis se tornou muito popular na Europa devido à sua atividade anti-bacteriana (CASTALDO, CAPASSO, 2002).

A própolis ganhou popularidade tanto na medicina alternativa ou suplemento dietético para a melhora da saúde e prevenção da doença em várias partes do mundo, incluindo Estados Unidos da América, União Européia e Japão (TEIXEIRA et al., 2005). A própolis produzida no sudeste do Brasil é conhecida como própolis verde devido à sua coloração (MARCUCCI et al., 1998). Herbalistas modernos recomendam o seu uso, pois ela exibe atividade antibacteriana, antifúngica, antiviral, hepatoprotetora, anti-inflamatório, propriedades imunomoduladores e anti-ulcerosas (REIS et al., 2000;. CASTALDO, CAPASSO, 2002).

Vários trabalhos têm sido publicados divulgando e revisando as propriedades biológicas da própolis como, por exemplo, atividade antimicrobiana (MARTINS et al., 2002; SCAZZOCCHIO et al., 2005), antifúngica (FERNANDES et al., 1995), antiprotozoária, antioxidante (RUSSO et al., 2002) , antiviral (COTARELO et al., 1999) e antitumoral (NOMURA, 2001). 
Hoje a própolis é usada como um remédio popular e está disponível na forma de cápsulas (seja na forma pura ou em combinação com o gel de aloe vera e rosa canina ou pólen); como um extrato (hidroalcoólico ou glicólico), como um enxaguatório bucal (combinado com melissa, sálvia, alecrim, malva), em pastilhas para a garganta, cremes e em pó (para ser usado em gargarejos ou para uso interno, ao invés de dissolvido em água). Também está disponível comercialmente como produto purificado em que a cera foi removida. A própolis também é reivindicada para ser útil em cosméticos e na composição de alimentos saudáveis (MARTINS et al., 2002).

Até hoje, de 180 a 300 compostos, principalmente os polifenóis, foram identificados como constituintes químicos da própolis. Os polifenóis importantes são os flavonóides, acompanhados de ácidos fenólicos e ésteres, aldeídos fenólicos, cetonas, etc. Outros compostos na própolis são óleos voláteis e ácidos aromáticos (5-10\%), ceras (30-40\%), resinas, bálsamos e pólen. São uma fonte rica de elementos essenciais, como magnésio, níquel, cálcio, ferro e zinco, embora a composição química da própolis tenha sido esclarecida nos últimos anos, ainda se observa uma variabilidade na sua composição química, dependendo do local de seu acervo (NIEVA MORENO et al., 1999; SFORCIN et al., 2000; CASTRO, 2001).

A variação da composição química da própolis está relacionada com sua origem botânica, sendo também a proporção das substâncias dependente dessa variação. Trabalhos de Sforcin et al. $(2000 ; 2002)$ já demonstraram que as atividades antimicrobianas frente a Staphylococcus aureus e Escherichia coli, bem como a atividade imunomoduladora, não variaram com a época da colheita da mesma. De qualquer forma, as concentrações dos constituintes ativos merecem atenção e controle e, por tal, o emprego de extratos 
padronizados é item imprescindível para a obtenção de medicamentos de origem natural (BERRETTA, 2003).

Biologicamente, as propriedades da própolis obviamente estão diretamente ligadas à sua composição química, e este, possivelmente, é o maior problema para o uso da própolis em "fitoterapia", tendo em vista que a sua composição química varia com a flora da região (KOO, PARK, 1996) e época da colheita (SANTOS 2003), com a técnica empregada, assim como com a espécie da abelha (no caso brasileiro também o grau de "africanização" da Apis melífera pode influenciar a sua composição). Somente no caso do Brasil são descritas propriedades biológicas e composição química distinta, para diferentes amostras coletadas em diferentes partes do país. Essa variação é facilmente explicada pela grande biodiversidade brasileira segundo Barud et al. (2007).

Há grande controvérsia em relação ao teor de flavonóides nas amostras brasileiras nas quais os ácidos fenólicos são geralmente bem mais abundantes. Atualmente, mais de 300 constituintes já foram identificados e/ou caracterizados em diferentes amostras de própolis, dentre eles: flavonóides, ácidos aromáticos, ácidos graxos, fenóis, aminoácidos, vitaminas A, B1, B2, B6, C, E e PP (encontradas na própolis de origem francesa), minerais como $\mathrm{Mn}, \mathrm{Cu}$, Ca, Al, Si, V, Ni, Zn e Cr3-5 (CASTRO, 2001; CASTALDO; CAPASSO, 2002).

A própolis é composta, basicamente por: $55 \%$ de resinas e bálsamos, $30 \%$ de cera, $10 \%$ de compostos voláteis e $5 \%$ de pólen e outros compostos inorgânicos. Uma menor variação da composição química da própolis é observada nas regiões temperadas do planeta, como na Europa, onde seus principais compostos bioativos são os flavonóides (flavonas, flavonóis e flavononas) (NIEVA MORENO et al. 1999; SFORCIN et al. 2000; HAVSTEEN, 2002). 
A própolis brasileira possui ácidos fenólicos prenilados, ligninas, terpenos, álcoois terpênicos e pequenas quantidades e flavonóides (AZEVEDO et al 1999).

Suas propriedades farmacológicas são atribuídas principalmente à presença dos flavonóides, principalmente ácidos fenólicos e derivados, os quais se caracterizam por apresentarem em suas estruturas químicas pelo menos um anel aromático ligado diretamente a ou mais hidroxilas. A opinião majoritária é que a nítida atividade biológica dos flavonóides se dá, em parte, pela capacidade de proteção contra ação agressiva dos radicais livres (RUSSO et al., 2002).

Recentemente, foi relatado que o éster fenetil ácido caféico (CAPE), presente no extrato de própolis, possui atividades farmacológicas, como quimioprofilaxia e antitumoral segundo Lee et al. (1999) e Borrelli et al. (2002). Além disso, estudos anteriores têm mostrado que o extrato etanólico de própolis privadas de CAPE foi menos potente do que o extrato com Cabo na inibição da ciclooxigenase (COX-1 e COX-2) de atividade em macrófagos (ROSSI et al., 2002).

A luz do fato, que a própolis possui atividade contra bactérias e inflamação e em perspectivas futuras, na redução da hipertensão arterial, hipercolesterolemia e apoptose celular, podendo ser proposta como "solução global" para doenças ateroscleróticas. Opinião corrente do uso do extrato padronizado da própolis é seguro e menos tóxico que muitos medicamentos sintéticos (CASTALDO; CAPASSO, 2002).

\subsection{Membrana de Celulose Bacteriana}

A celulose é o biopolímero mais abundante na Terra. Os organismos fotossintéticos tais como plantas, algas e algumas bactérias produzem mais de 100 milhões toneladas da 
matéria orgânica todos os anos pela fixação do dióxido de carbono, sendo que a metade desta biomassa é composta do biopolímero celulose. A celulose é o principal componente da madeira, do algodão e das outras fibras têxteis tais como o linho e a juta (ramie), segundo Pérez, Mackie (2001).

A celulose bacteriana pode ser obtida de diferentes fontes, tais como plantas, síntese enzimática, síntese química, além de alguns microorganismos que possuem esta habilidade, incluindo Sarcina, Agrobacterium, Rhizobium e Acetobacter. Entretanto, a Acetobacter xylinum é a única espécie conhecida capaz de produzir celulose em grandes quantidades comerciais (MORMINO, 2002).

Industrialmente, a celulose é muito usada na produção de papel, na indústria madeireira, como emulsificador, agente dispersante, agente gelificante, entre outras. Atualmente, a madeira do eucalipto tem sido uma das principais fontes industriais de celulose, que é composta por celulose (40 a 45\%), lignina (25 a 30\%), hemiceluloses (30\%) e extrativos (até 4\%), segundo Barud et al. (2006) .

A fibra de celulose bacteriana (CB) produzida pela bactéria do gênero Acetobacter xylinum tem algumas características como a alta cristalinidade, resistência à tração, elasticidade, durabilidade, elevada capacidade de absorção e retenção de água, mas sua principal diferença com relação a outros tipos de celulose encontrada é o tamanho da fibra produzido pela bactéria (KLEMM et al., 2005). Além disso, a CB é um polímero biodegradável e biocompatível, não tóxico e não alergênico (JONAS, FARAH, 1998).

De forma geral, a bactéria excreta entre 50-80 microfibrilas de celulose que possuem 3,0 a 3,5 nm de largura. Em seguida, as microfibrilas se agregam, formando fitas. A celulose obtida possui aspecto de membrana gelatinosa, que se forma na interface meio de culturasuperfície. Alguns autores sugerem que as bactérias constroem "casulos" para si, a fim de se 
protegerem contra inimigos externos, metais pesados, ou radiação ultra-violeta (RECOUVREX ET al. 2004).

A celulose produzida por bactérias possui a mesma composição química da celulose produzida por plantas, porém com propriedade mecânicas e estruturais diferentes. Comparando com a celulose sintetizada por plantas, a CB possui maior capacidade de reter água, é mais cristalina, possui maior resistência à tração, maior área de superfície e sua microestrutura são constituídas de nanofibras (JONAS, FARAH, 1998).

A $\mathrm{CB}$ pertence a uma das classes mais promissoras de biopolímeros, devido às propriedades peculiares únicas, não apresentadas por outros biomateriais. A celulose produzida por bactérias é altamente pura, uniforme, biocompatível - exigência necessária para biomateriais (MATTHEWS, RAWLINGS, 1994); possui grande capacidade de retenção de líquidos, propriedade importante para aplicações médicas e de engenharia de tecidos, como adjuvante em tratamentos de lesões da pele, ou ainda na produção de vasos sanguíneos e suportes para produtos médicos de engenharia de tecidos (SILVESTRE FILHO, 2001).

\subsubsection{ESTRUTURA QUÍMICA E FÍSICA}

A celulose é um polissacarídeo formado por moléculas de $\beta$-D-glicopiranose em longas cadeias, não ramificadas, unidas por ligações glicosídicas $\beta(1 \rightarrow 4)$ (BIELECHI et al. 2005), que permite uma rotação de $180^{\circ}$ da unidade seguinte de glicose ao redor do eixo C1C4 do anel de piranose. A configuração dos átomos de carbono da celulose faz com que as cadeias sejam essencialmente lineares, não tendendo a se enrolar em estruturas helicoidais, como os polímeros de glicose com ligações $\alpha(1 \rightarrow 4)$, como o amido (HISANO, 2006). O polímero linear de celulose é fortemente associado através das ligações de hidrogênio que são 
responsáveis pela formação das fibras de celulose (WILLIANS e CANNON 1989). (Figura $1)$.

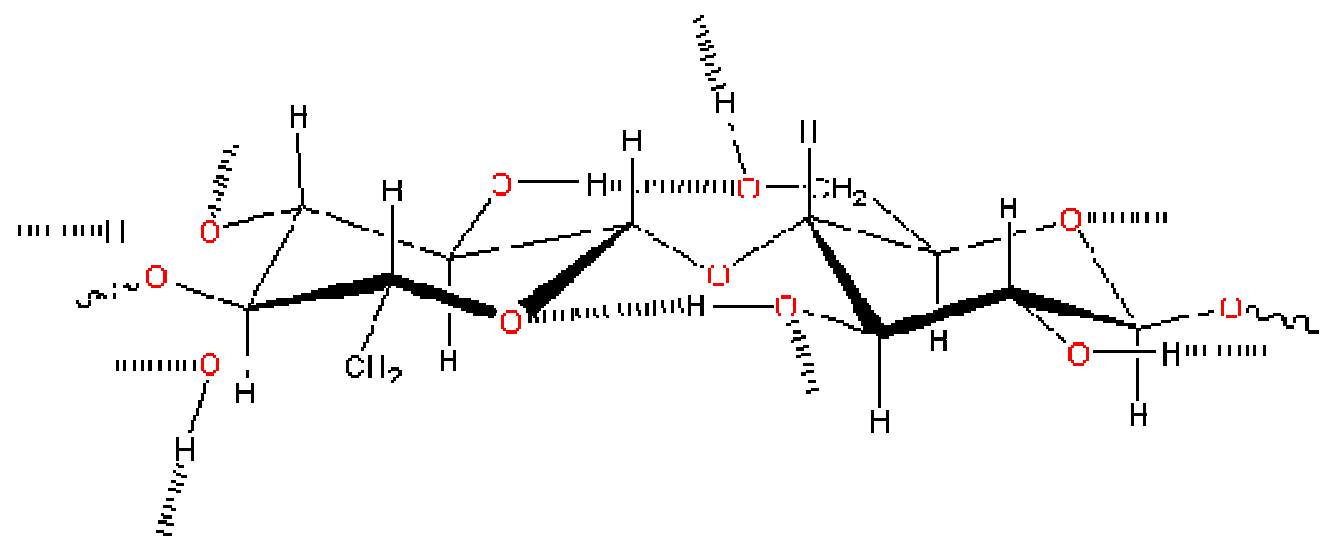

Figura 1 - Estrutura linear da celulose. As linhas pontilhadas esquematizam as ligações de hidrogênio possíveis (HISANO,2006).

A unidade monomérica é constituída de duas unidades de glicose ligadas pela eliminação de uma molécula de água entre seus grupos hidroxílicos nos carbonos 1 e 4, e o comprimento da unidade repetitiva é de 1,03 nm (PÉREZ, MACKIE, 2001). Apesar da presença de grupos $\mathrm{OH}$ nas duas extremidades da cadeia de celulose, estes grupos apresentam comportamentos distintos. O grupo $\mathrm{OH}$ do carbono $1(\mathrm{C} 1-\mathrm{OH})$ é um grupo derivado de um aldeído hidratado da formação do anel por uma ligação hemicetal intramolecular, razão pela qual o grupo $\mathrm{OH}$ do $\mathrm{C} 1$ possui propriedades redutoras. Os grupos hidroxilas livres da celulose podem formar ligações de hidrogênio intra e intermoleculares. Através dessas ligações de hidrogênio, formam-se arranjos cristalinos que são geralmente imperfeitos a longas distâncias. Deste modo, a celulose apresenta-se como fibras compostas de regiões ordenadas (cristalinas) e desordenadas (não-cristalinas). A predominância de cada região varia de acordo com a origem da celulose (BLEDZKI, GLASSAN, 1999). 
A reatividade da celulose está diretamente ligada a cada unidade de $\beta$-D- glicopiranose que formam as cadeias do polissacarídeo. Em cada unidade contém uma hidroxila primária e duas hidroxilas secundárias livres que representam um papel importante na transformação química da celulose na maioria dos seus derivados (BLEDZKI, GLASSAN, 1999). São estes grupos funcionais que provavelmente reagem parcialmente com os agentes de acoplamentos utilizados na formação da interface.

A relação da $\mathrm{CB}$ com os reagentes orgânicos e inorgânicos é pequena, devido às fortes interações entre os grupos hidroxilas, que proporciona uma estrutura rígida, estável e de grande resistência à tração e também por sua baixa solubilidade frente à água e diversos solventes orgânicos. Mas, é possível fazer modificações estruturais na celulose, devido aos grupos hidroxilas. Algumas das possíveis modificações são a metilação, esterificação, sulfonação e nitração (HEINZE, LIEBERT, 2001).

Quanto à estrutura física, a CB é semelhante à celulose produzida pelas plantas. Entretanto, ela é obtida na forma de um hidrogel altamente hidratado (99\% água), sendo quimicamente pura (livre de lignina, hemicelulose, e pectinas). Apresenta cadeias de celulose nanométrica ("nanocelulose"), organizadas em um arranjo estrutural tri-dimensional, o qual gera um sistema altamente cristalino (60-80\%), com excelente força mecânica. Essa rede de fios nanométricos lhe confere enorme área superficial, surpreendente capacidade de absorção e retenção de água, boa elasticidade, além de ser facilmente moldável (JONAS, FARAH, 1998).

A celulose pode ser obtida a partir de diferentes origens e esse fato influencia nas suas propriedades físico-químicas, como: grau de pureza, de polimerização e cristalinidade.

Devido a essas diferenças nas características da celulose classificou-se a mesma em quatro diferentes formas: Celulose I, II, III e IV ( BROWN JR, 1999). 
- Celulose I ou Celulose Nativa é a forma mais abundante, possui duas fases cristalinas, celulose I $\alpha$ e celulose I $\beta$. Essas duas fases coexistem dentro de uma mesma microfibrila e varia de acordo com a natureza da celulose. Por exemplo: celulose produzida por organismos primitivos (bactérias e algas) possui mais fase I $\alpha$, enquanto a celulose das plantas superiores (tecido lenhoso, algodão, rami, entre outras) coexiste principalmente a I $\beta$. A fase I $\beta$ é termodinamicamente mais estável (Figura 2). Assim, é possível converter a fase I $\alpha$ a I $\beta$, mas o inverso não ocorre (BROWN JR, 1999).

Vanderhart, Atalla (1987) propuseram que a celulose I apresenta duas fases cristalinas alomorfas, I $\alpha$ ocorre predominantemente em celuloses produzidas por algas e bactérias e apresenta um arranjo triclínico, enquanto a fase I $\beta$ ocorre na celulose das plantas superiores com um sistema monoclínico. A proporção das fases cristalinas nas fibras de celulose está diretamente relacionada com as propriedades mecânicas do material (BROWM JR, 1990).

a)

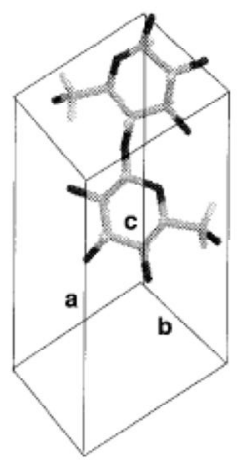

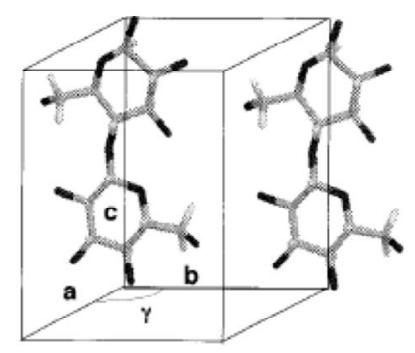

b)

Figura 2 - Representação da cela unitária das fases (a) I $\alpha$ (b) I $\beta$ (KOYAMA et al., 1997)

- Celulose II ou Celulose Regenerada pode ser obtida pela mercerização da celulose I ou pela solubilização seguida por regeneração (reprecipitação). A celulose II é mais estável que a celulose I e o processo não é reversível. 
- Celulose III pode ser obtida pela celulose I e II. Por celulose I o processo é reversível e é classificada como celulose III-I e pela celulose III-II, através de tratamento com amônia líquida ou com certas aminas, como: etilenodiamina (celulose III-I) (O’SULLIVAN, 1997; PÉREZ, MACKIE, 2001).

- Celulose IV é derivada da Celulose III tratada a alta temperatura $\left(206^{\circ} \mathrm{C}\right)$ em glicerol e pode ser dividida em dois tipos: Celulose IV-I que é obtida da celulose III-I e a Celulose IVII da celulose III-II (O’SULLIVAN, 1997; PÉREZ, MACKIE, 2001).

O primeiro meio de obtenção da celulose é de grande importância industrial e o mais popular, que se refere à obtenção da celulose por meio das plantas, sendo a celulose isolada da parede celular dos vegetais. O segundo meio é a biossíntese feita por diferentes tipos de microorganismos, por exemplo: Vallonia (alga); Saprolegnia e Dictystelium discoideum (fungos); Acetobacter, Agrobacterium, Aerobacter, Pseudomonas e Sarcina (bactérias) (JONAS, FARAH, 1998; KLEMM et al., 2001). Os meios, terceiro e quarto, são sínteses in vitro que compreendem a síntese enzimática $\left(3^{\circ}\right)$ e quimiossíntese $\left(4^{\circ}\right)$.

A CB pode ser sintetizada por vários gêneros de bactérias, porém o gênero que pode ser utilizado para produções industriais é o Acetobacter xylinum, atualmente reclassificada como do gênero Glucanoacetobacter (KLEMM et al., 2006); (Figura 3). Ela foi primeiramente descrita por Brown em 1886 (ATALLA, 1999). A A.xylinum é uma bactéria gram-negativa, aeróbica e não fotossintética capaz de converter glicose, glicerol e outros substratos orgânicos em celulose dentro de poucos dias, sendo encontrada, geralmente, em frutas, vegetal, vinagre, suco de frutas e bebidas alcoólicas (CHENG ET AL., 2002; HISANO, 2006; KLEMM et al., 2006). 

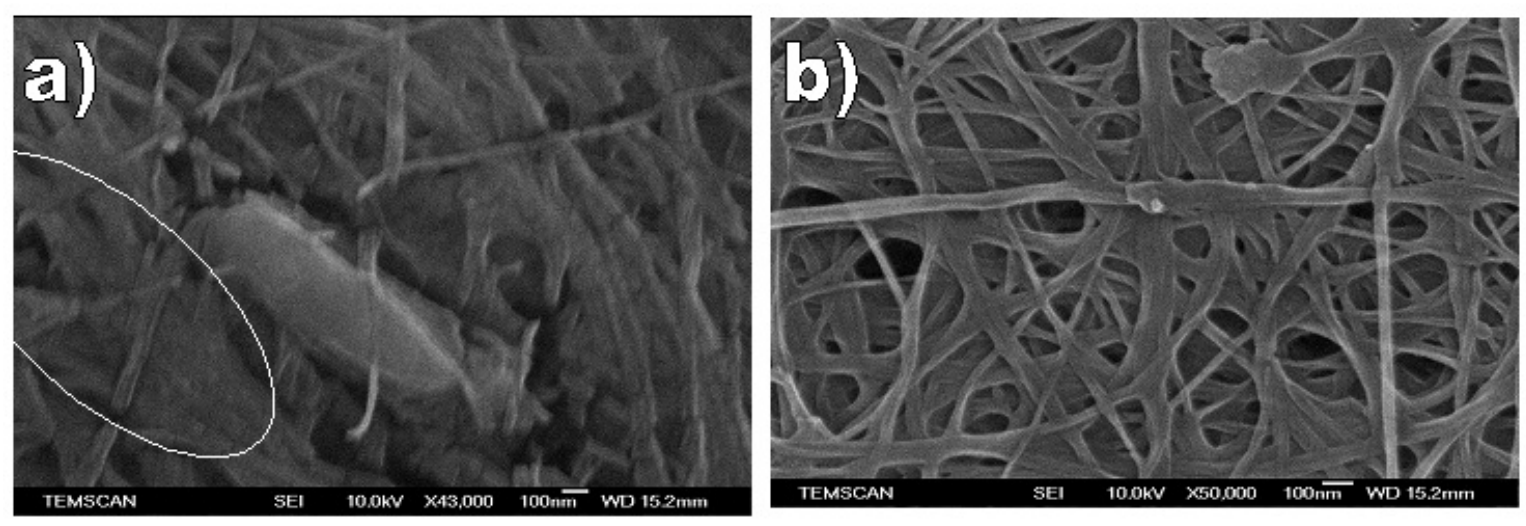

Figura 3 - Microscopia eletrônica de varredura da CB a) Em destaque a bactéria Acetobacter Xilinum; b) As microfibras de celulose podem ser claramente observadas (KLEMM, 2006).

\subsubsection{SÍNTESE DA CB}

A CB é sintetizada em forma de uma membrana gelatinosa extremamente hidratada, que absorve uma massa de 60 a 700 vezes a sua própria massa segundo Barud (2006). A membrana é formada na interface ar/meio de cultura, com uma pureza maior que a celulose vegetal $(\mathrm{CV})$, sendo que esta contém hemicelulose, lignina e compostos menores (orgânicos e inorgânicos) que formam uma matriz rígida da parede celular na planta (KLEMM et al., 2005; HISANO, 2006).

A biossíntese da CB não é totalmente conhecida. Sabe-se que A. xylinum sintetiza a celulose por complexos terminais associados a poros na superfície, paralelos ao eixo longitudinal da célula (Figura 4). Na formação da celulose, em uma primeira etapa, aproximadamente 16 cadeias de glicose se agregam, formando uma fibrila $(\sim 1,5 \mathrm{~nm}$ de largura) que é agrupada numa segunda, para formar as microfibrilas que se unem para formar as fitas com largura entre 40-60 $\mathrm{nm}$. Estas fitas se entrelaçam formando as fibras que constituem a película ou membrana de celulose (HIRAI, TSUJI, HORII, 2002; KLEMM et al., 2005). Na Figura 5, observa-se que as células de A. xylinum ficam distribuídas ao longo da rede de fibras de celulose. Devido à todo esse processo de formação das fibras de celulose, é 
que as características estruturais e a razão $\mathrm{I} \alpha / \mathrm{I} \beta$ da CB dependem da cepa e das condições de cultivo (KLECHKOVSKAYA et al., 2003).

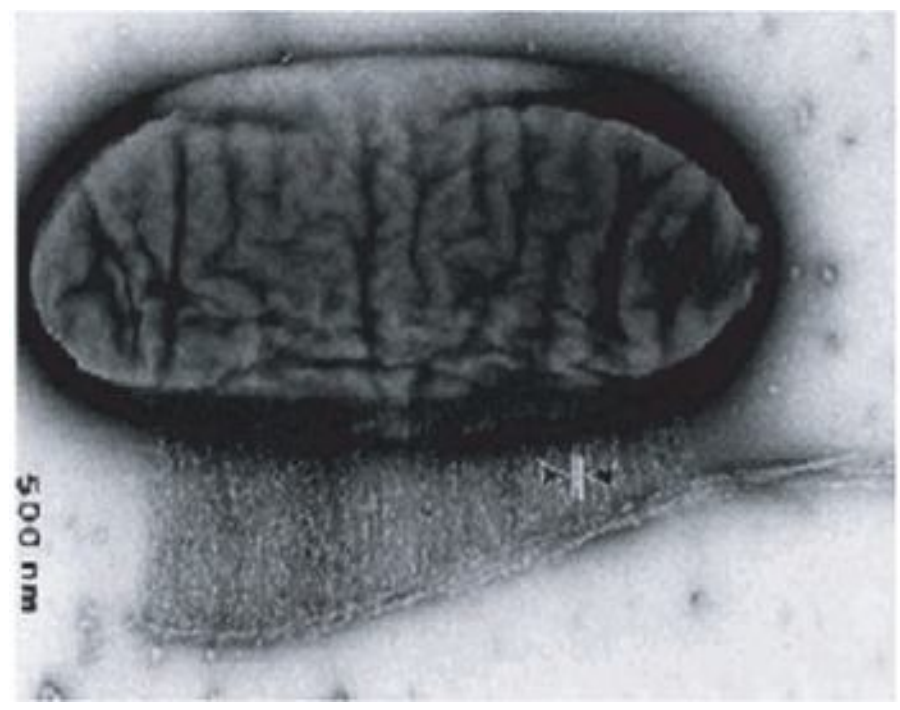

Figura 4 - Micrografia eletrônica de transmissão da bactéria A. xylinum durante a produção de celulose (HIRAI, TSUJI, HORII, 2002).

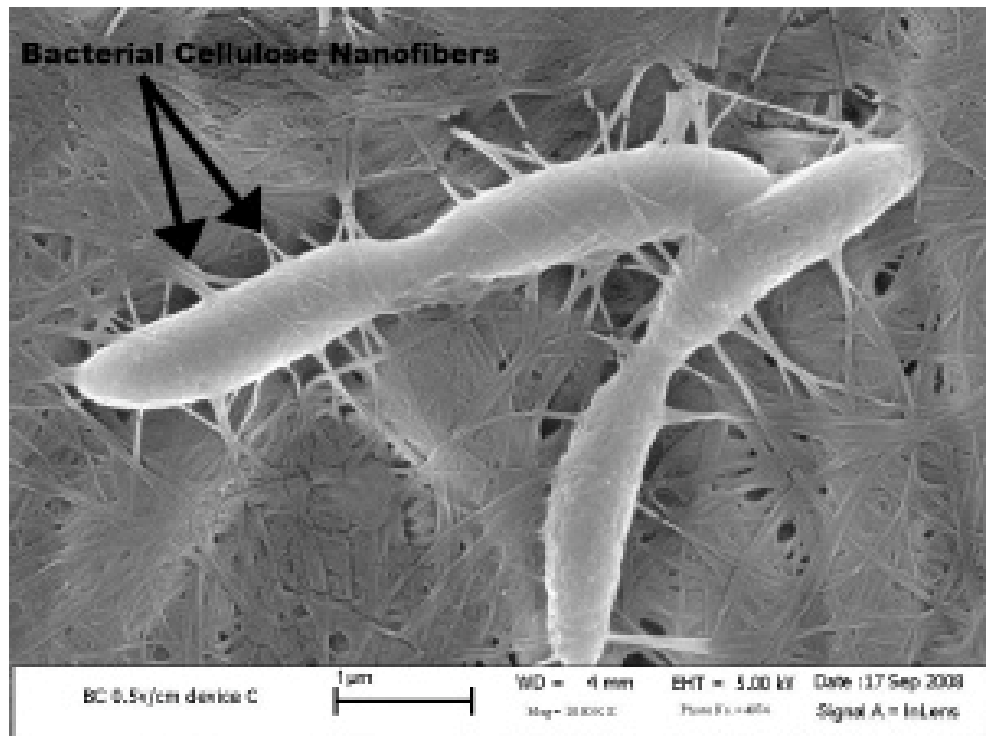

Figura 5 - Micrografia eletrônica de varredura da rede de celulose incluindo as células bacterianas A. xylinum (IGUCHI, YAMANAKA, BUCHIONO, 2000). 
A membrana "in natura" (Figura 6) pode passar por diferentes processos de secagem, por estufa ou pelo processo de liofilização. A Figura 7 ilustra a membrana seca, onde os espaços entre as cadeias estão mais colapsados, diferente das membranas hidratadas que possui um espaço maior entre as cadeias devido, principalmente, às ligações de hidrogênio.

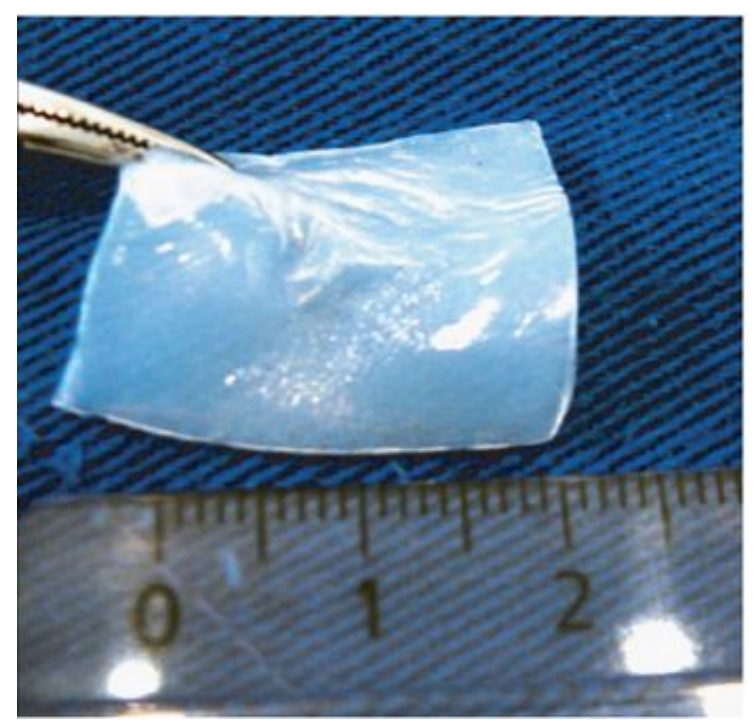

Figura 6 - Foto da membrana de CB in natura (CZAJA et al., 2006).
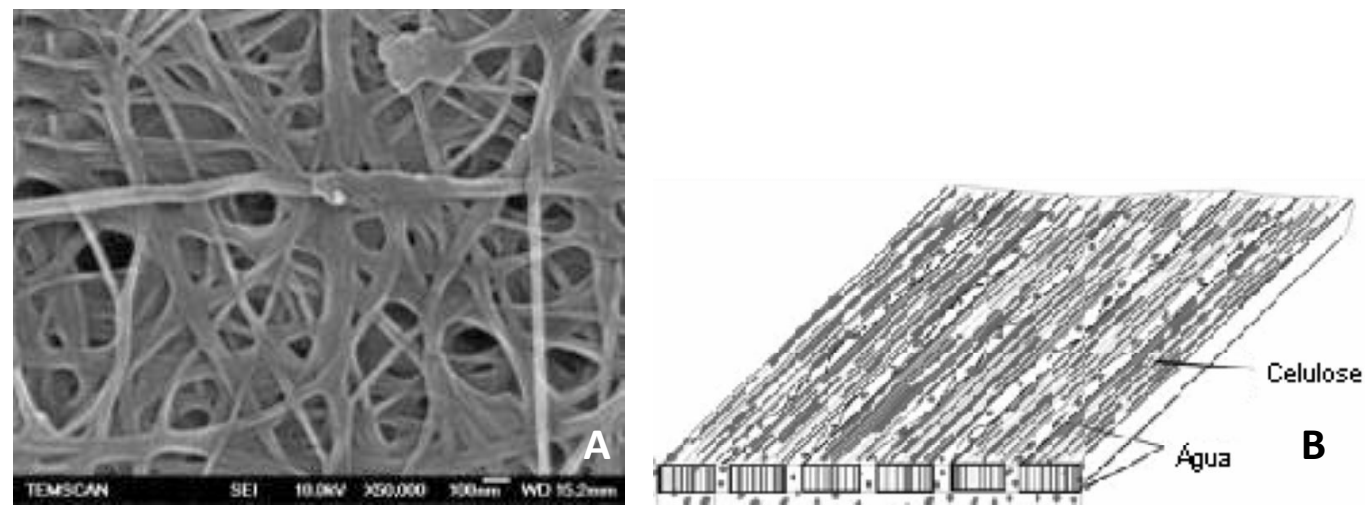

Figura 7 - (A) Micrografia eletrônica de varredura da CB seca; (B) modelo das microfibrilas hidratadas da celulose bacteriana (KLEMM et al., 2005).

A produção da $\mathrm{CB}$ varia dependendo da cepa utilizada; cepas de A. xylinum são capazes de produzir num intervalo de 48 e 96 horas, dentro de um meio de cultura bastante 
simples, uma quantidade de celulose que um eucalipto levaria meses. Supõe-se que $10000 \mathrm{~kg}$ de $\mathrm{CB}$ podem ser obtidos anualmente numa cultura estática de um hectare e somente $600 \mathrm{~kg}$ de algodão são colhidos no mesmo período de tempo em uma mesma área (STEINBÜCHEL, DOI, 2005). 


\section{MATERIAIS E MÉTODOS}

\subsection{Preparações das Membranas de Celulose Bacteriana}

As mantas de celulose bacteriana (CB) foram fornecidas pela empresa Fibrocel Produtos Biotecnológicos LTDA, situada em Ibiporã (PR). O cultivo das bactérias Acetobacter xylinum (cepa superprodutora) foi realizado em meio de cultura estática, que apresentou a composição segundo a Tabela 1:

Tabela 1 - Composição do meio de cultura

\begin{tabular}{l|c}
\multicolumn{1}{c|}{ Componentes } & $\%(\mathbf{m} / \mathbf{v})$ \\
\hline Glicose & 2,0 \\
\hline Peptona & 0,5 \\
\hline Extrato de levedura & 0,27 \\
\hline Fosfato de sódio bibásico anidro & 0,27 \\
\hline Ácido cítrico monoidratado & 0,15 \\
\hline
\end{tabular}

A cultura das bactérias foi realizada em bandejas de 30x50cm, com tempo de cultivo de 96 horas à $28^{\circ} \mathrm{C}$. Em meio de cultura estática, a celulose foi obtida em forma de uma membrana gelatinosa formada na interface meio de cultura/superfície. Para remover as bactérias, a membrana passou por tratamento com uma solução diluída de hidróxido e hipoclorito de sódio por 30 minutos, sendo posteriormente lavada exaustivamente em água destilada. 


\subsection{Membrana de celulose associada à própolis (CBP)}

As CBS e CBH (99 \% água) foram imersas em soluções de extrato etanólico de própolis padronizado $\left(\mathrm{EPP}-\mathrm{AF}^{\circledR}\right)$, fornecido pela empresa Apis Flora Indl. Coml. Ltda., obtidos sob diversas concentrações [12, 24 e $36 \%$ (p/v) de extrato alcoólico a $11 \%$ de resíduo seco], com objetivo final de obter, respectivamente, $1,2 \% ; 2,4 \%$ e $3,6 \% \mathrm{p} / \mathrm{v}$ de resíduo seco por membrana, conforme Berretta $(2003 ; 2007)$, durante o período de 24 horas. A fim de se obter boa uniformidade e homogeneidade, as amostras foram secas em moldes de "nylon" similares a um bastidor, sob temperatura de $37^{\circ} \mathrm{C}$ por 12 horas, segundo fluxograma apresentado na Figura 8.

As amostras de $\mathrm{CBH}$ foram exaustivamente submetidas a um processo de troca de solventes (água por etanol), pois algumas substâncias que compõem a própolis possuem caráter hidrofóbico e são solúveis em ambiente alcoólico.

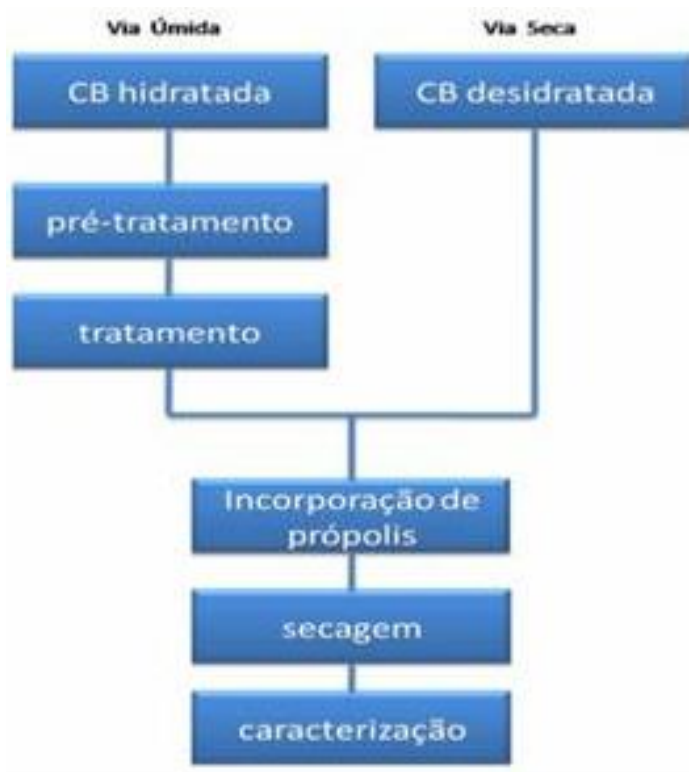

Figura 8 - Fluxograma do desenvolvimento da CBP. 


\section{3 PROCEDIMENTO EXPERIMENTAL}

\subsubsection{Caracterização Físico-Química e Morfológica das CBP}

\subsubsection{A Difração de Raios-X (DRX)}

Os dados de Difração de Raios-X (DRX) foram obtidos em um difratograma Siemens D5000 sob as seguintes condições experimentais: $2 \theta=4 \mathrm{o}-70 \mathrm{o}$, passo de $0,05 / 1 \mathrm{~s}$, e radiação $\mathrm{K} \alpha$ do cobre $(\lambda=1,5406 \AA)$. Essa análise teve como objetivo analisar a cristalinidade da celulose e dos compósitos formados.

\subsubsection{B Espectroscopia Vibracional na Região do Infravermelho} (FTIR)

As análises foram realizadas através de um espectrômetro com transmissão Fourier Shimadzu (FTIR - 8300), para as amostras de celulose bacteriana e para os compósitos obtidos, com acessório Gateway ATR. As condições utilizadas foram: \% de Transmitância com acúmulo de 32 Varreduras, com resolução de $4 \mathrm{~cm}^{-1}$ na faixa de absorção de 4000-370 $\mathrm{cm}^{-1}$.

\subsubsection{Microscopia Eletrônica de Varredura (MEV)}

A morfologia da fibra e dos compósitos foi analisada em um microscópio eletrônico FEG-SEM JSM 6330F no Laboratório Nacional de Luz Sincroton (LNLS), usando uma tensão de $10 \mathrm{kV}$. 


\subsubsection{Termogravimetria e Análise Térmica Diferencial (TG/DTA)}

As análises termogravimétrica e térmica diferencial foram feitas no equipamento SDT Q-600 da TA Instruments, sob as seguintes condições:

- Massa da amostra $\sim 10 \mathrm{mg}$;

- Faixa de aquecimento $-25{ }^{\circ} \mathrm{C}$ a $600 \circ \mathrm{C}$;

- Razão de aquecimento - $20 \circ$ C.min ${ }^{-1}$;

- Atmosfera - Nitrogênio (vazão do gás $=50 \mathrm{ml} / \mathrm{min}^{-1}$ ),

- Cadinho de alumina.

O objetivo dessa análise foi estudar a estabilidade térmica das amostras de fibra nos diferentes estados, das resinas sintetizadas e dos compósitos obtidos.

\subsubsection{Testes Microbiológicos}

O ensaio antimicrobiano foi realizado para cepa de Staphilococcus aureus, por ser a bactéria mais frequentemente envolvida nos processos infecciosos em estudos realizados com própolis, sendo testadas diluições nas concentrações de própolis de $0,02 \%$ a 5,5\%.

\subsubsection{A Padronização do método da macrodiluição para determinação da atividade antimicrobiana do EPP-AF}

\section{A.1. Padronização do inóculo}

Para o método da macrodiluição, o CLSI recomenda que seja preparada uma suspensão microbiana inicial de aproximadamente $1.10^{8}$ a $2.10^{8} \mathrm{UFC} / \mathrm{ml}$, o que equivale à escala 0,5 de McFarland. As suspensões avaliadas nos experimentos foram medidas com o auxílio de espectrofotômetro. Portanto, foi realizada a padronização do inoculo nas condições 
utilizadas com o objetivo de encontrar a melhor absorbância da suspensão de $S$. aureus ATCC 25923 e 43300 contendo aproximadamente $1.10^{8} \mathrm{UFC} / \mathrm{ml}$.

\section{A.2. Padronização do método da macrodiluição}

No método da macrodiluição preconizado pelo CLSI (2000), após o período de incubação, os tubos são avaliados quanto à turvação do meio de cultura. Se o meio estiver límpido, significa que os microrganismos foram inibidos. Por outro lado, se o meio estiver turvo, significa que os microrganismos não foram inibidos e, portanto, cresceram no meio de cultura. Assim, é possível avaliar a Concentração Inibitória Mínima (CIM) do produto, a qual é considerada a menor concentração do produto que é capaz de inibir o crescimento microbiano. No caso da própolis, o meio de cultura torna-se turvo devido às características físicas da mesma, como a coloração e a precipitação de alguns compostos. Portanto, não se sabe se a turvação é atribuída ao crescimento microbiano ou às características físicas da própolis. Sendo assim, foi necessário semear o conteúdo de cada tubo (com o auxilio de uma alça bacteriológica) em uma placa de Petri (90x15mm) contendo Agar Mueller Hinton, a fim de confirmar se havia ou não microrganismos viáveis. Nesse caso, é avaliada a Concentração Bactericida Mínima (CBM) do produto, a qual é considerada a menor concentração do produto que é capaz de matar os microrganismos avaliados. 


\section{RESULTADOS E DISCUSSÃO}

As amostras CBH estão no seu estado natural, em que sua composição é praticamente 99\% de água, que está relacionada com valores já apresentados em trabalhos anteriores (KLEMM et al., 2001 e 2005). A amostra CBP úmidas contém, além da água, uma quantidade de solvente, pois ela passou por um processo de lavagem. O processo de troca de solvente nas membranas úmidas de celulose já foi relatado em alguns trabalhos (KLEMM, 2006 e KRAMER et al., 2006), porém o método com os solventes específicos utilizados neste trabalho não foi encontrado. Os solventes escolhidos para a realização da lavagem foi o álcool etílico, que forma um azeótropo com a água (DUBEY et al., 2002 e PANDEY, SAXENA, DUBEY, 2005), diminuindo a porcentagem de água gradualmente. De acordo com Klemm et al. (2006), a CB também apresenta boa afinidade com outras misturas de solventes orgânicos

As membranas CBP apresentaram coloração âmbar, a qual pode ser atribuída a presença de própolis adsorvido; essa coloração é mais evidente nas membranas obtidas via úmida e a coloração tornou-se mais intensa com o aumento da concentração de própolis.

\section{A. Microscopia Eletrônica de Varredura}

Observaram-se que as fibrilas produzidas por Acetobacter xylinum possuem um tamanho menor que $1 \mathrm{~m}$, de aspecto compacto e com fibras longas (figura 9a), também observado por Czaja et al. (2006). As figuras 9b e 9c mostram imagens de superfície das amostras $\mathrm{CBS}$ e $\mathrm{CBH}$, ambas preparadas com extrato de própolis a 2,4\% m/v. As micrografias revelam o total recobrimento das microfibras da $\mathrm{CB}$ pela presença de própolis. As membranas obtidos via úmida apresentaram a formação de pequenos grumos, que pode estar associado à elevada concentração de própolis absorvidas pela celulose hidratada. A presença de própolis é 
mais acentuada nas membranas obtidas via hidratada, pois as mesmas apresentam uma estrutura com a "malha" aberta, ou seja, altamente porosa, comportamento não observado na CBS, onde os poros estão colapsados.

A figura 9d mostra uma imagem de secção transversal para a membrana $\mathrm{CBH}$ com própolis; a micrografia apresentada sugere fortemente a difusão da própolis para os interstícios da celulose.

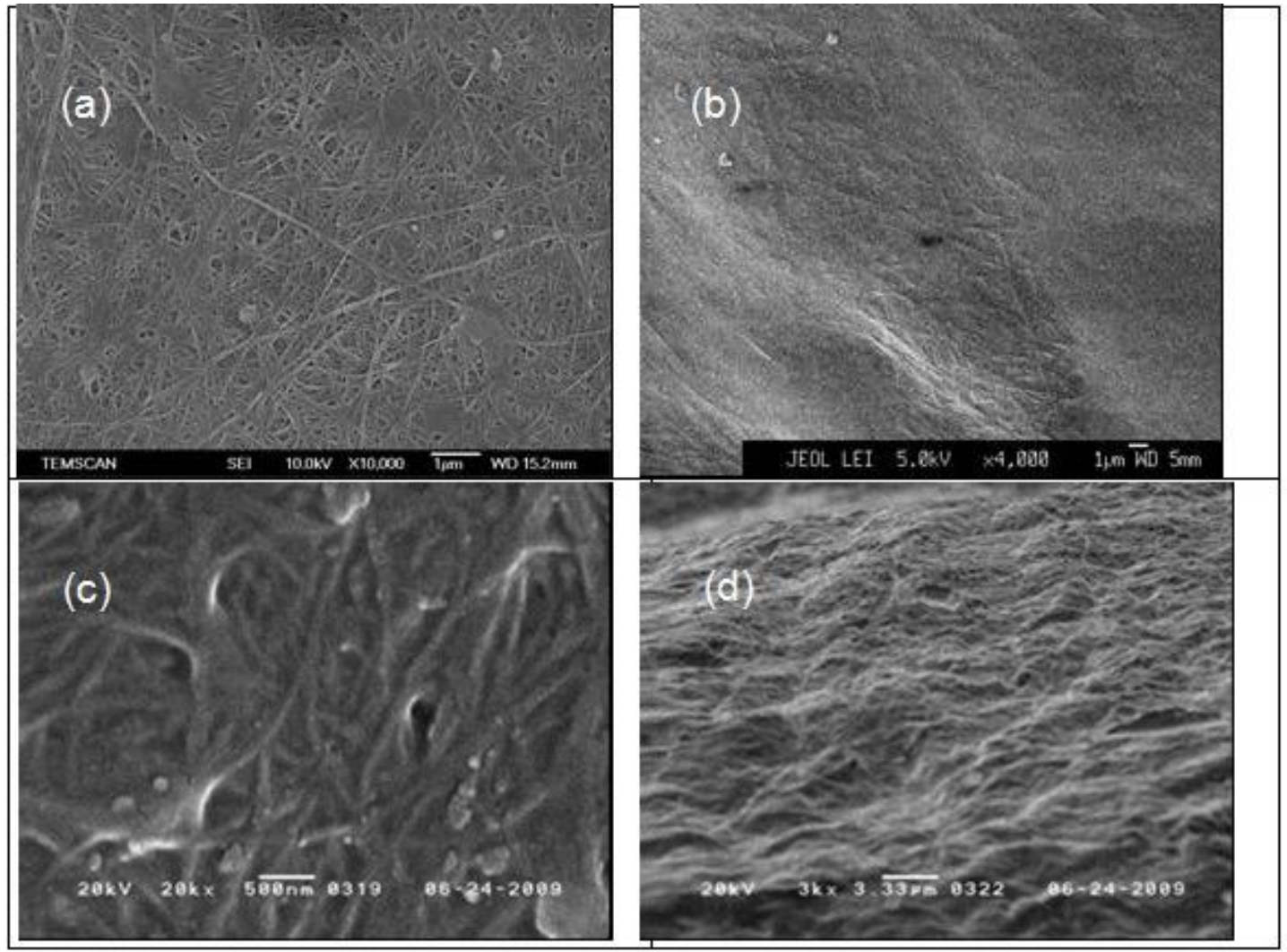

Figura 9. Imagens da Microscopia Eletrônica de Varredura: (a) Imagem de superfície de celulose; (b) Imagem de superfície da membrana CBS-própolis 2,4\%; (c) Imagem de superfície da membrana CBH-própolis 2,4\%; (d) Secção Transversal da membrana CBHprópolis $2,4 \%$.

O estudo da morfologia de fibras é muito importante, sendo possível observar as fibras em seu real tamanho, sua organização, sua direção preferencial e alguma falha na sua estrutura (SAWYER e GRUBB, 1996). Essas informações podem ser úteis para o estudo das 
propriedades mecânicas das fibras e dos seus compósitos formados. A organização morfológica da CB é definida por fibras que são formadas pela junção das microfibrilas. As microfibrilas possuem dimensões entre 3 a $20 \mathrm{~nm}$, dependendo da sua origem segundo Klemm et al, (2005).

A análise morfológica da CB foi estudada por MEV e demonstrou que as fibras têm um alto entrelaçamento sem direção preferencial. Mesmo com uma ampliação de 6000x não foi possível visualizar os poros da amostra CBS, e enquanto a $\mathrm{CB}$ liofilizada possui uma estrutura altamente porosa (HISANO, 2006), demonstrando que a porosidade da amostra de CB liofilizada tem maior porosidade que a fibra seca.

A tabela 2 apresenta resultados referentes à espessura e a rugosidade das membranas CBP via seca e via úmida.

Tabela 2. Medidas de espessura e rugosidade para CB e CBP.

\begin{tabular}{l|l}
\hline Amostra & Espessura \\
\hline CBS pura & $35 \mu \mathrm{m}$ \\
CBS-própolis $2,4 \%$ & $86 \mu \mathrm{m}$ \\
CBH pura (seca $\left.50^{\circ} \mathrm{C}\right)$ & $75 \mu \mathrm{m}$ \\
CBH-própolis $2,4 \%$ & $350 \mu \mathrm{m}$ \\
\hline
\end{tabular}

Quando se compara a CB a CBP, ocorre um aumento tanto na espessura da membrana; desta forma este aumento é um indício da presença de própolis.

É importante observar também que a CBH-própolis possue um aumento na espessura de quase cinco vezes quando comparados à $\mathrm{CB}$, enquanto, as membranas CBS-própolis apenas dobram o valor de espessura; desta forma a CBH é capaz de incorporar uma quantidade superior de própolis. 


\section{B. Difratometria de Raios $X$}

A figura 10 apresenta os resultados de Difratometria de raios-X para a CB e as membranas CBS-própolis e CBH-própolis, respectivamente.
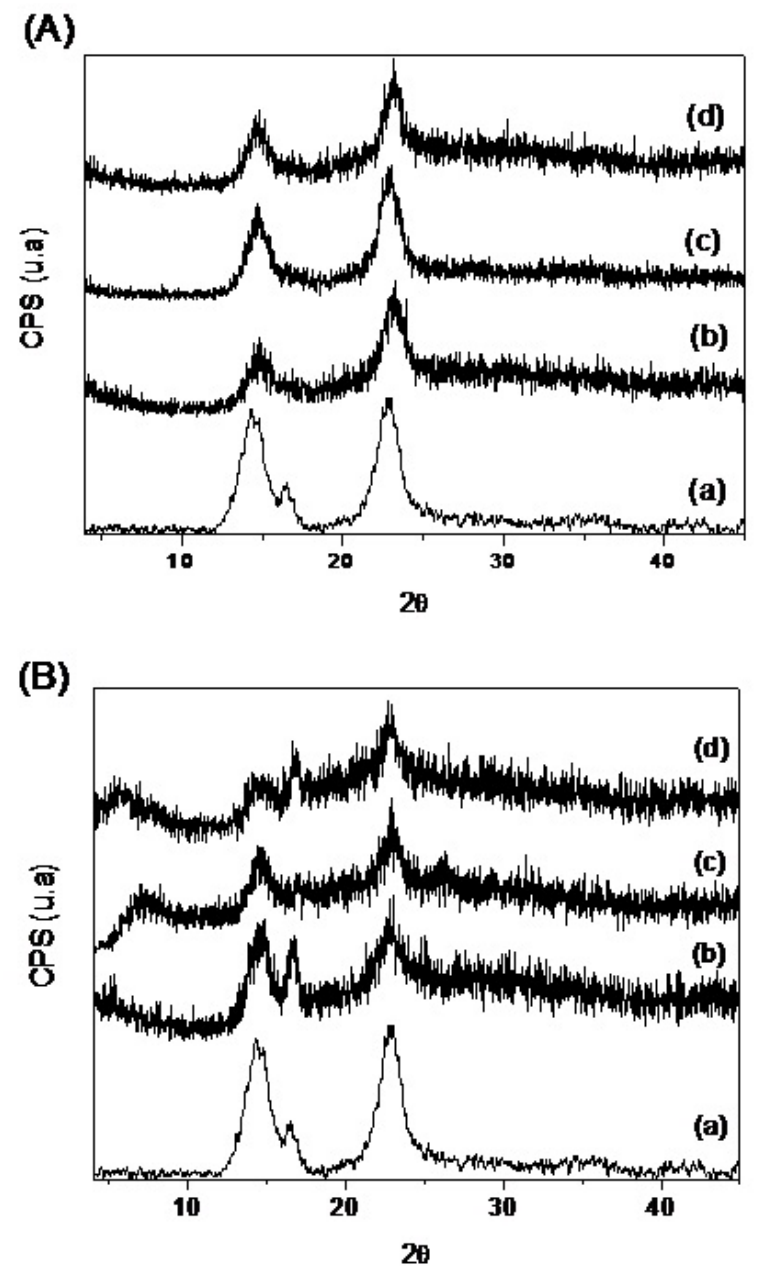

Figura 10. Difratograma de Raios-X de: Espectro(A) CB, (a) CB pura, (b) CBS-própolis 1,2\%, (c) CBS-própolis 2,4\%; (d) CBS-própolis 3,6\%; Espectro (B): (a) CB; (b) CBH-própolis 1,2\%; (c) CBH-própolis 2,4\%; (d) CBH-própolis 3,6\%.

De maneira geral, a presença de própolis nas membranas CBS-própolis não altera significativamente a cristalinidade da $\mathrm{CB}$, sugerindo que grande parte da própolis esteja apenas adsorvida superficialmente. 
Entretanto, os difratogramas das membranas $\mathrm{CBH}$-própolis, revelam uma diminuição gradual na cristalinidade da $\mathrm{CB}$ com o aumento da concentração de própolis. Pode-se inferir que a própolis não se encontra apenas na superfície da membrana, mas está presente também nos interstícios, e nesse caso, tornando o polímero mais amorfo.

A celulose bacteriana (CB) é um polímero semicristalino. Existem duas fases cristalinas presentes na $\mathrm{CB}$ : fase $\mathrm{I} \alpha$ e $\mathrm{I} \beta$ que correspondem às estruturas triclínica e monoclínica, respectivamente. Em estudo de WADA, SUGIYAMA e OKANO, 1993, os picos comuns identificados estão aproximadamente em $14^{\circ}, 17^{\circ}$ e $22,5^{\circ}$. Os picos em $14,4^{\circ} \mathrm{e}$ $17^{\circ}$ correspondem às difrações dos planos triclínico (100) e monoclínico (110). O pico em $22,8^{\circ}$ representa os planos triclínico (110) e monoclínico (200).

Para a CB, em um estudo de Antoinnete (1997), observou-se a difração em apenas dois ângulos, em 15 e 22,5 graus. Cada pico difratado apresenta uma contribuição das difrações correspondentes as fases I $\alpha$ (estrutura triclínica) e I $\beta$ (estrutura monoclínica), devido à sobreposições das reflexões dos planos $100_{\mathrm{I} \alpha}, 110_{\mathrm{I} \beta}$ e $010_{\mathrm{I} \alpha}$ em $15^{\circ}$ e dos planos $110_{\mathrm{I} \alpha}$ e 200 I $\mathrm{e}$ em $22,5^{\circ}$ (sobreposição). Observou-se que o processo de secagem causou uma diferença na organização das fases, ocorrendo um pequeno desvio. Esse comportamento já foi observado também em Manzani (2004).

Os resultados mostraram que o processo de secagem influência na cristalinidade, pois as amostras passaram por processos diferentes de secagem e a cristalinidade encontrada para cada uma foi diferente. Resultados semelhantes aos encontrados em estudo de Manzani em 2004. 


\section{C. Espectroscopia Vibracional de na Região do Infravermelho}

A figura 11 apresenta resultados de espectroscopia vibracional na região do infravermelho para membranas de CB e para as membranas CB-própolis.
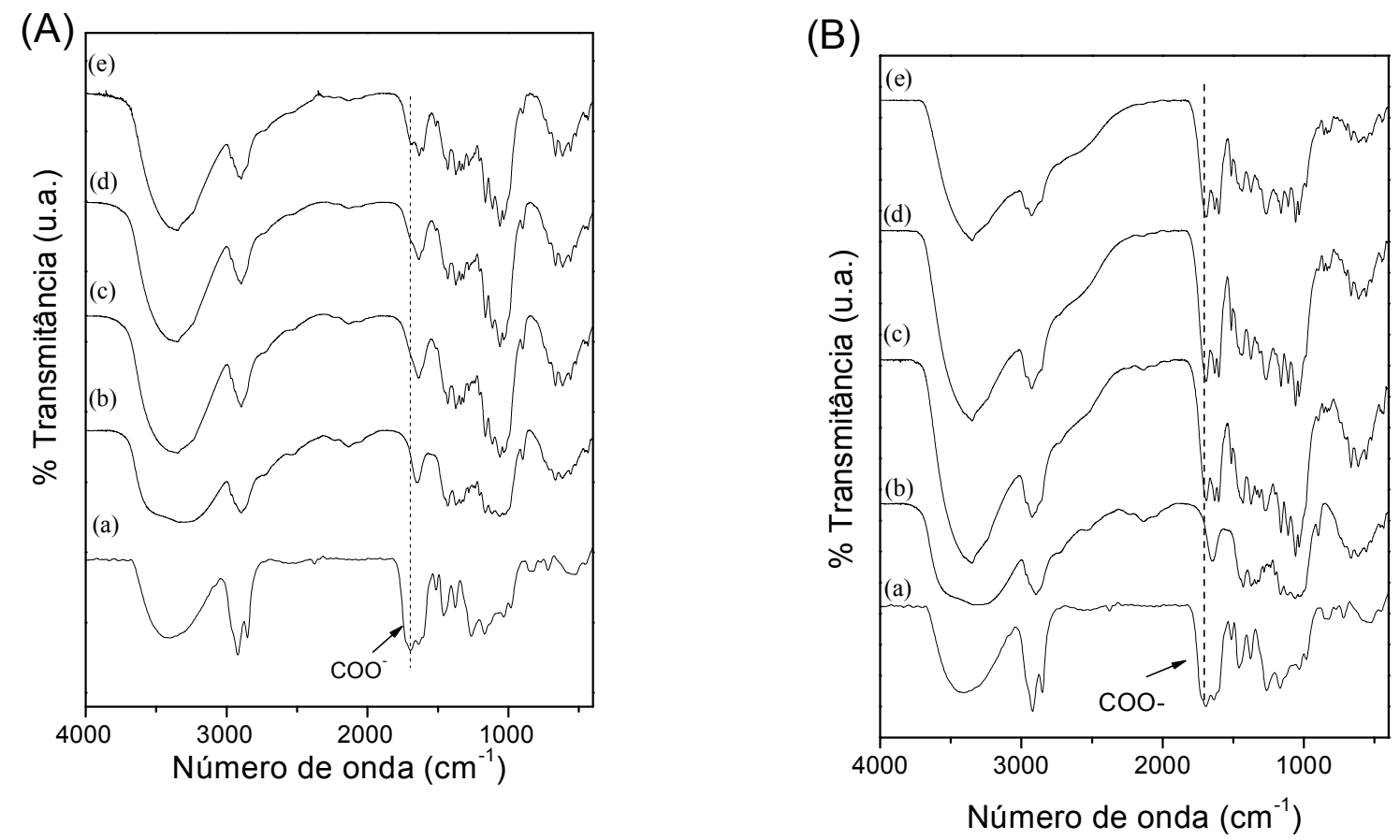

Figura 11. Espectroscopia Vibracional na Região do Infravermelho de: Espectro (A): (a) própolis; (b)CB;(c) CBS-própolis 1,2\%; (d) CBS-própolis 2,4\%; (e) CBS-própolis 3,6\% ; Espectro (B): (a) própolis; (b)CB; (c) CBH-própolis 1,2\%; (d) CBH-própolis 2,4\%; (e) CBH-própolis 3,6\%.

Neste trabalho, basicamente, os espectros referentes às membranas CBP podem ser considerados como a somatória das bandas presentes na membrana e na própolis, isto é, são observadas contribuições referentes às vibrações características tanto da $\mathrm{CB}$ e também da própolis, evidenciando, portanto, a formação de um material compósito.

Não foi observado o surgimento de uma nova banda nas membranas CB-própolis, muito embora, o aumento gradual da concentração de própolis nas membranas gera um alargamento na banda localizada ao redor de $3500 \mathrm{~cm}^{-1}(v \mathrm{OH})$. Esse alargamento é mais evidenciado nas membranas CBH-própolis, e deve estar associada, principalmente, a formação de ligações de hidrogênio entre a celulose e a própolis. 
A presença de própolis nas membranas pôde ser confirmada através da banda localizada ao redor de $1700 \mathrm{~cm}^{-1}$, característica dos grupos carboxila. Essa banda presente exclusivamente na própolis pura, aparece de forma discreta no espectro dos compósitos CBSprópolis, sugerindo que a própolis esteja adsorvida principalmente na superfície da membrana de CB. Entretanto, essa banda apresentou-se mais pronunciada nas membranas CBH-própolis, sugerindo a presença de própolis não apenas na superfície, mas também entre as cadeias de glicose.

Algumas bandas que caracterizam a própolis são absorções referentes à presença de ligação dupla $\mathrm{C}=\mathrm{C}\left(\operatorname{vmax} 1641 \mathrm{~cm}^{-1}\right)$, de grupos carboxila $\left(\right.$ vmax $\left.1703 \mathrm{~cm}^{-1}\right)$ e hidroxílico $\left(\right.$ vmax $\left.3487 \mathrm{~cm}^{-1}\right)$. A contribuição da banda $\mathrm{OH}$ próximo a $3300 \mathrm{~cm}-1$ para as amostras pode estar relacionada à estrutura da fibra e também a presença de água que pode estar adsorvida (BANKOVA et al., 1998).

\section{D. Análise Termogravimétrica (TG) e Calorimetria Exploratória}

\section{Diferencial (DSC)}

As curvas TG para a CB e CBP são apresentadas na figura 12. 
(A)

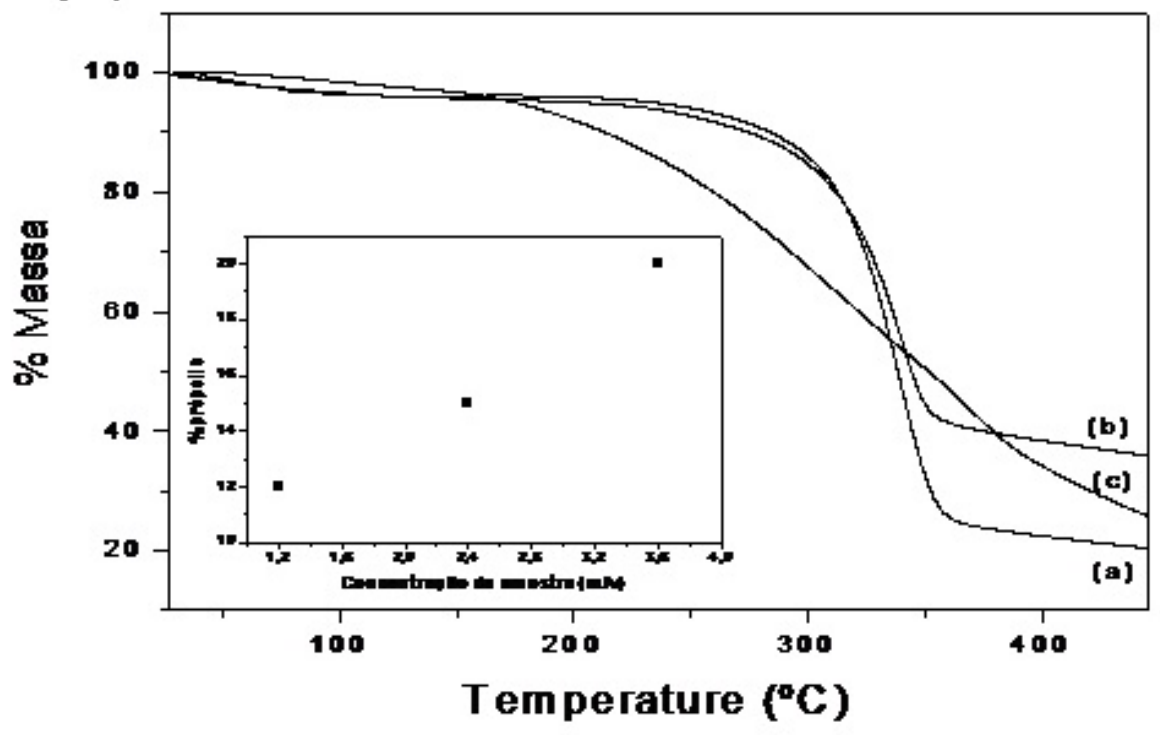

(B)

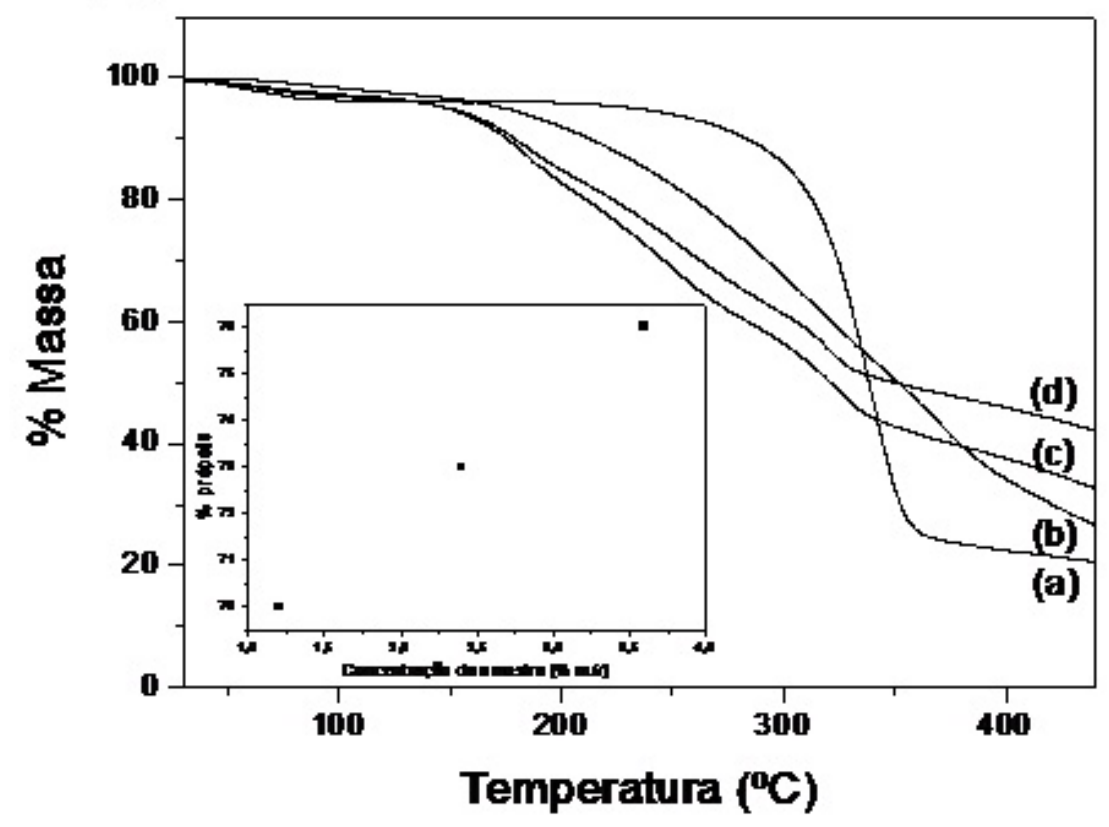

Figura 12. Análise Termogravimétrica de: Curva (A): (a) CB ; (b) própolis (c) CBS- própolis 2,4\%; Curva (B): (a) CB ; (b) própolis, (c) CBH-própolis 1,2\%; (c) CBH-própolis 2,4\%; (d) CBH-própolis $3,6 \%$. 
A celulose apresentou uma perda de massa de aproximadamente $5 \%$ na faixa de temperatura entre $45-150^{\circ} \mathrm{C}$. Essa perda de massa foi confirmada por um evento endotérmico observado na curva DSC, e pode ser atribuída à desidratação da membrana, como, por exemplo, evaporação de água adsorvida. Um evento bem acentuado com grande perda de massa (aproximadamente 60\%) foi observado na faixa de temperatura que compreendeu o intervalo de $250^{\circ} \mathrm{C}$ a $350^{\circ} \mathrm{C}$. Esse evento foi observado na curva DSC através de um pico exotérmico com máximo em aproximadamente $350^{\circ} \mathrm{C}$, o qual está relacionado a processos de degradação da celulose como despolimerização e posterior decomposição das unidades glicosídicas, seguido da formação de resíduos carbonáceos.

A estabilidade térmica de $\mathrm{CB}$ encontrada na literatura foi de $150^{\circ} \mathrm{C}$ (GEORGE et al., 2005), para as membranas que não passavam por um tratamento e $275^{\circ} \mathrm{C}$ para as membranas que passavam por um tratamento térmico. Portanto, a fibra de CB estudada não passou por um tratamento semelhante e apresentou uma estabilidade térmica $\left(250^{\circ} \mathrm{C}\right)$ próxima à temperatura das membranas que passaram por esse tratamento.

A própolis apresentou uma pequena perda de massa de aproximadamente $4 \%$, com início em apenas $60^{\circ} \mathrm{C}$ e prossegue até aproximadamente $180^{\circ} \mathrm{C}$, referente principalmente à processos de desidratação e perda de solvente. Uma grande perda de massa de aproximadamente $65 \%$ foi observada na faixa de temperatura entre $190-450{ }^{\circ} \mathrm{C}$, e pode ser atribuída à diversos eventos, incluindo condensação de grupos $\left(\mathrm{OH}^{-}\right)$, quebras de ligações carbônicas, e posterior degradação dos compostos orgânicos.

No trabalho de Pinto (2002), observou-se que as amostras de CB apresentaram resíduos superiores a $10 \%$, isso pode ser explicado devido à atmosfera de nitrogênio utilizada nas análises. Como a atmosfera de nitrogênio é inerte não ocorrerá a oxidação completa da 
matéria orgânica e os resultados mostraram que os resíduos das amostras foram menores que $2 \%$.

A temperatura de transição vítrea para a CB foi determinada em outros trabalhos. Os valores encontrados para a $\mathrm{CB}$ sem modificação foi $-23^{\circ} \mathrm{C}$ em $\mathrm{DSC}$, em concordância com o valor encontrado na literatura (MANZANI, 2004). Porém o valor da TG abrangeu valores de $-13^{\circ} \mathrm{C}$ até $13{ }^{\circ} \mathrm{C}$ para a CB sem tratamento, e para celulose microcristalina, que possui uma alta porcentagem de celulose, a cristalinidade, encontrada foi entre $140^{\circ} \mathrm{C}$ a $180^{\circ} \mathrm{C}$ (GEORGE et al, 2005). Toda essa diferença está relacionada com as diversas fontes de celulose, com o método de secagem, o meio de cultura, tempo de cultivo, pois esses fatores influenciam na cristalinidade, que é um fator relevante na determinação da TG (PRINCI, 2005).

Quanto às membranas CBS-própolis, observou-se grande similaridade com o perfil térmico da $\mathrm{CB}$, enquanto as membranas $\mathrm{CBH}$-própolis apresentaram um perfil térmico muito similar a própolis pura.

Notou-se que membranas tanto via úmida, quanto via seca, apresentaram um processo de desidratação com início ao redor de $50^{\circ} \mathrm{C}$, o qual é muito similar ao processo de desidratação da celulose.

Observou-se ainda que a presença da própolis não causou alterações significativas na estabilidade térmica da celulose. Para as membranas CBH-própolis, observou-se um pequeno decréscimo na estabilidade térmica da membrana de cerca de $10^{\circ} \mathrm{C}$, e que pode estar associado à quebra de ligações de hidrogênio entre as cadeias de biocelulose, devido à elevada massa de própolis incorporada à $\mathrm{CB}$. Esse resultado corrobora a resultados obtidos via difração de Raios-X, aonde observou-se pequenas alterações na cristalinidade da CB.

Através do resíduo da curva TG foi possível estimar a porcentagem de própolis presente nos membranas de celulose, notando-se que as membranas $\mathrm{CBH}$-própolis apresentam 
um maior teor de própolis comparado às membranas CBS-própolis. Esse comportamento está associado ao método de partida utilizado na preparação das membranas, pois a membrana hidratada é capaz de não apenas adsorver própolis na superfície, mas absorvê-la também em seus interstícios, possibilidade não encontrada nos membranas via seca, como já anteriormente discutido nos resultados de MEV. Apesar das amostras estarem secas, a água permanece adsorvida na sua estrutura devido ao seu caráter hidrofílico.

As figuras 13 (A) e (B) trazem os resultados envolvendo a porcentagem de própolis presentes nas membranas, e que foram estimadas em função dos resíduos obtidos nas curvas TG.
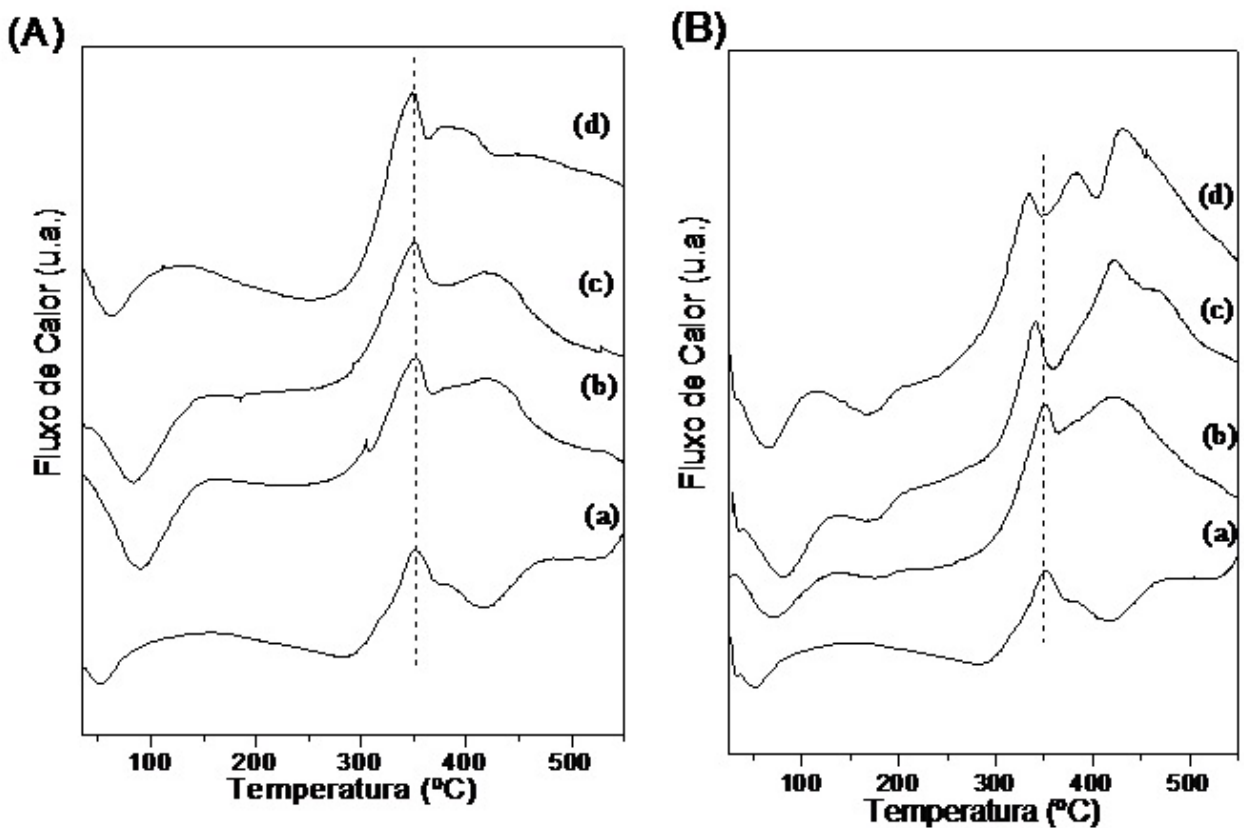

Figura 13: Curva DSC de: Curva (A): (a) CB pura; (b) CBS-própolis 1,2\%; (c) CBS-própolis 2,4\%; (d) CBS-própolis 3,6\%, Espectro (B): (a) CB pura; (b) CBH-própolis 1,2\%; (c) CBH-própolis 2,4\%; (d) CBH-própolis 3,6\%. 
De maneira geral, observou-se um aumento gradual na massa de própolis nas membranas à medida que se aumentou a concentração de própolis nas soluções iniciais $(1,2$, $2,4,3,6 \% \mathrm{~m} / \mathrm{v})$.

\section{E. Teste Microbiológico}

5E1. Avaliação da Atividade Antimicrobiana de Membranas contendo

\section{Extrato Padronizado de Própolis (EPP-AF)}

A tabela 3 mostra a absorbância das suspensões e o número de $S$. aureus obtido nos ensaios para a padronização do inóculo inicial.

Tabela 3. Absorbância das suspensões e número de S. aureus ATCC 25923 obtido nos ensaios para a padronização do inoculo inicial.

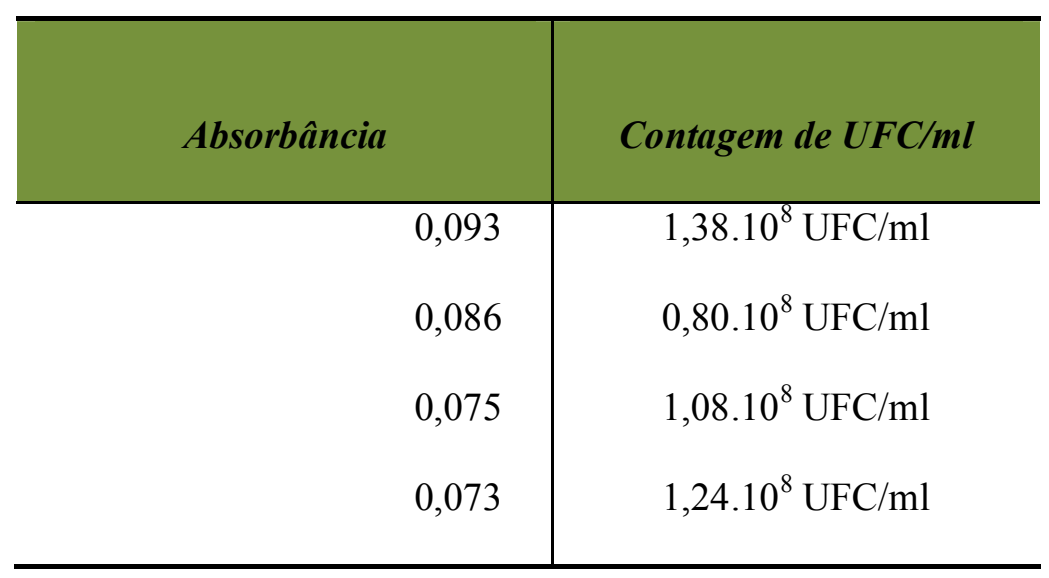

Os resultados obtidos mostram que as absorbâncias entre 0,073 e 0,086 foram as melhores, pois neste intervalo a contagem de colônias esteve dentro dos limites preconizados pelo CLSI.

O CLSI também recomenda que a suspensão inicial seja diluída e que $1 \mathrm{ml}$ da mesma seja adicionado a cada tubo de ensaio da macrodiluição. A concentração final do 
inoculo em cada tubo deve ser de aproximadamente $5.10^{5} \mathrm{UFC} / \mathrm{ml}$. Portanto, foi necessária a padronização do inóculo final. A tabela 4 mostra a absorbância das suspensões e o número de S. aureus obtido nos ensaios para a padronização do inóculo final.

Tabela 4. Absorbância das suspensões e número de $S$. aureus ATCC 25923 obtido nos ensaios para a padronização do inoculo final.

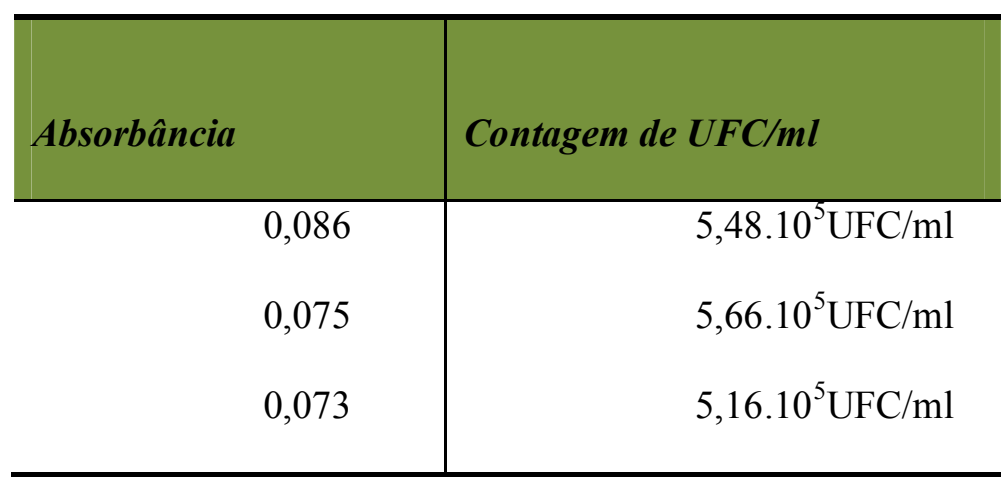

Esses resultados mostraram que absorbâncias próximas a 0,07 são as mais adequadas para as suspensões de $S$. aureus utilizadas no método da macrodiluição, pois na absorbância 0,073 foi encontrado o valor mais próximo de $5 \cdot 10^{5} \mathrm{UFC} / \mathrm{ml}$. Observou-se ainda que tanto nos experimentos de padronização para $1.10^{8} \mathrm{UFC} / \mathrm{ml}$ como para $5.10^{5} \mathrm{UFC} / \mathrm{ml}$, valores de absorbância maiores nem sempre resultaram em um número maior de UFC. Isso pode ser explicado pelos erros inerentes à metodologia, como a uma possível redução no número de microrganismos viáveis durante o experimento devido à sensibilidade das células bacterianas. Portanto, a absorbância considerada melhor, não pode ser definida como um número absoluto, mas em intervalos, neste caso de 0,073 a 0,086 . Destaca-se ainda que o microrganismo de escolha para a padronização das suspensões foi o $S$. aureus foi devida à sua conhecida sensibilidade à própolis. Portanto, ele foi escolhido como microrganismo indicador 
para a padronização do método da macrodiluição para avaliar a atividade antimicrobiana do EPP-AF (Figura 14).

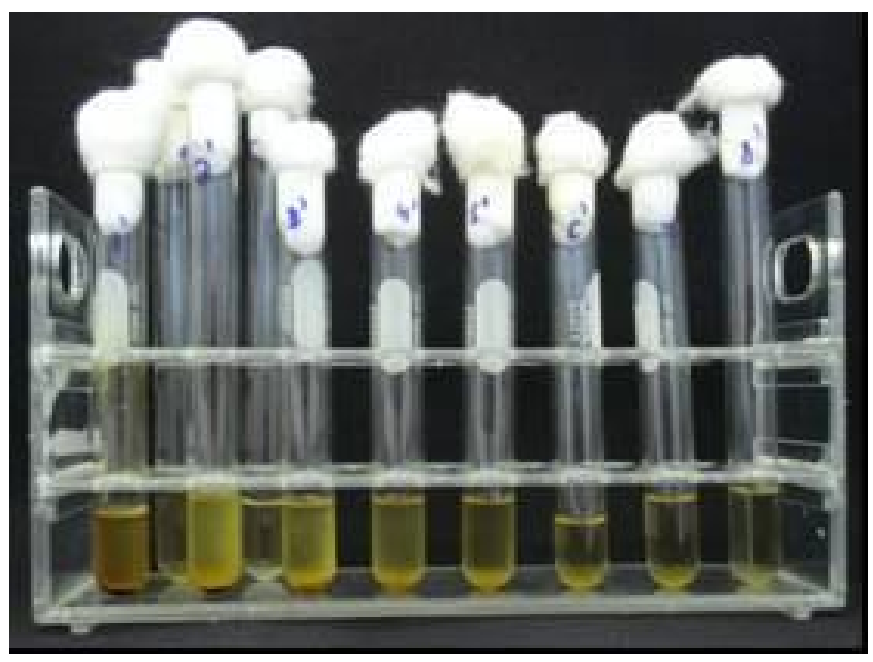

T5 T6

Figura 14. Atividade antimicrobiana do EPP-AF frente ao S. aureus ATCC 25923 por meio do método da macrodiluição.

A figura 14 mostrou que houve crescimento microbiano a partir do tubo 6 (T6) (diluição1/64), ou seja, o EPP-AF matou os microrganismos até a diluição $1 / 32$ do tubo 5 (T5). A concentração de extrato seco de própolis no EPP-AF é de $11 \%$. Isso significa que na diluição $1 / 32$, a concentração de extrato seco foi de $0,34 \%$. Portanto, a CBM do EPP-AF frente ao S. aureus ATCC 25923 foi de 0,34\%. Para a padronização do método, esse experimento foi realizado três vezes, sendo que os resultados obtidos em todos eles foram os mesmos, Tabelas 5 e 6. 
Tabela 5. Atividade antimicrobiana (Concentração Bactericida Mínima - CBM) do extrato padronizado de própolis (EPP-AF) frente ao S. aureus ATCC 25923, utilizando o método da macrodiluição.

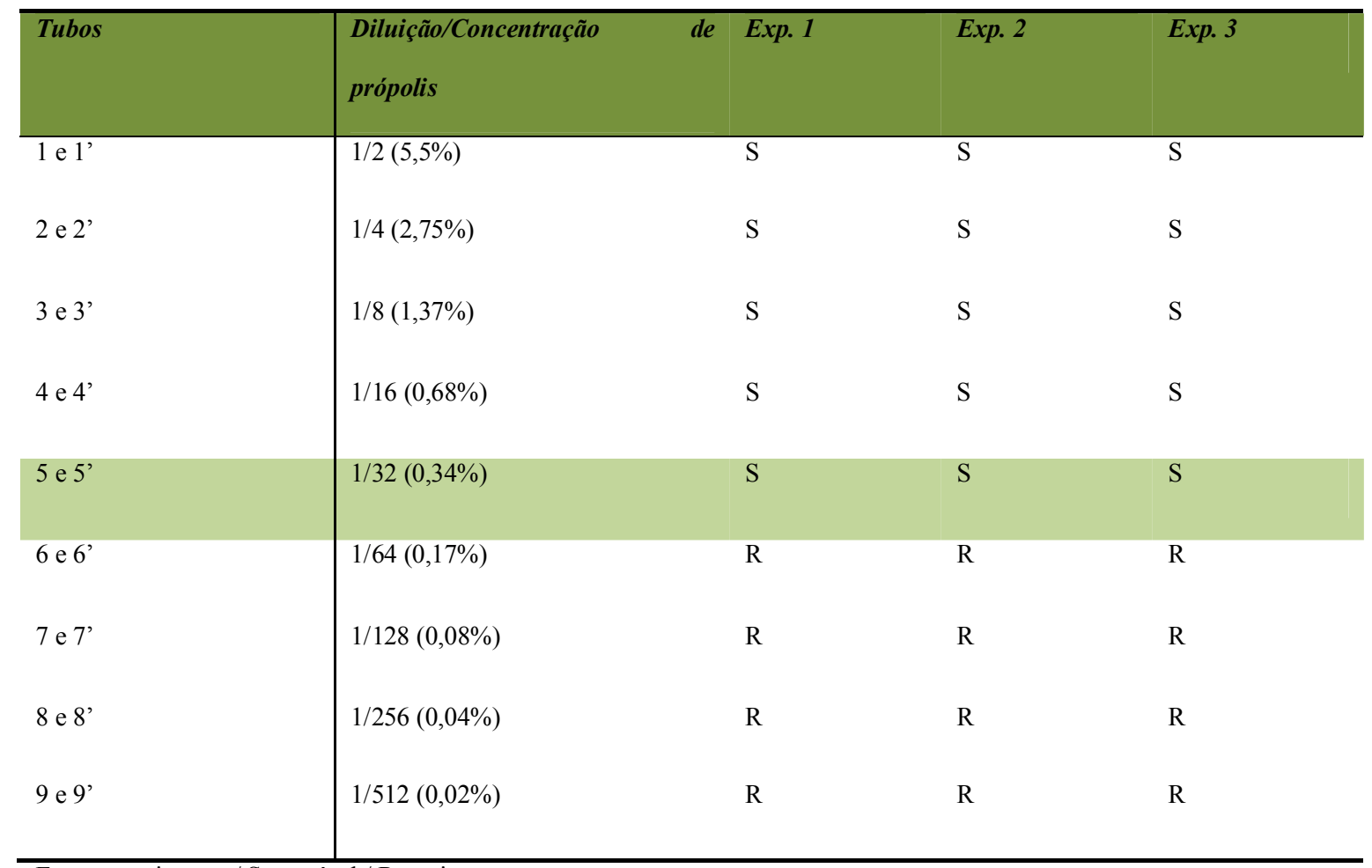

Exp.: experimento / S: sensível / R: resistente 
Tabela 6. Atividade antimicrobiana (Concentração Bactericida Mínima - CBM) do extrato padronizado de própolis (EPP-AF) frente ao S. aureus ATCC 25923, utilizando o método da difusão em Agar

\begin{tabular}{l|c}
\hline Diluição/Concentração de própolis & Média dos diâmetros dos halos de inibição (mm) \\
\hline $1 / 2(5,5 \%)$ & 11 \\
$1 / 4(2,75 \%)$ & 10 \\
$1 / 8(1,37 \%)$ & 8 \\
$1 / 16(0,68 \%)$ & 8 \\
$1 / 32(0,34 \%)$ & $\mathrm{R}$ \\
$1 / 64(0,17 \%)$ & $\mathrm{R}$ \\
$1 / 128(0,08 \%)$ & $\mathrm{R}$ \\
$1 / 256(0,04 \%)$ & $\mathrm{R}$ \\
$1 / 512(0,02 \%)$ & \\
\hline
\end{tabular}

Tabela 1

$\mathrm{R}$ - Resistente

A atividade antimicrobiana da própolis é atribuída principalmente aos flavonóides. O EPP-AF apresenta $5,74 \mathrm{mg} / \mathrm{ml}$ de flavonóides totais em sua composição. $\mathrm{Na}$ concentração de 0,34\% (CBM do EPP-AF frente ao S. aureus ATCC 25923), ele apresentou $0,17 \mathrm{mg} / \mathrm{ml}$ de flavonóides totais, o que indica a potente atividade desse extrato frente ao $S$. aureus agindo mesmo em concentração muito baixa. Com base nesse experimento pode-se 
dizer que as membranas de celulose devem conter a concentração mínima de $0,34 \%$ de EPPAF para que tenham atividade antimicrobiana contra $S$. aureus.

O mecanismo da atividade antimicrobiana da própolis é complexo e pode ser atribuído à atividade sinérgica entre os compostos fenólicos e outros (KROL et al., 1993).. Na $\mathrm{Na}$ própolis, a atividade antibacteriana tem sido correlacionada com o teor galangina, que foi indicado como sendo o principal responsável para a atividade bactericida (PEPELJNJAK, KOSALEC, 2004). O sinergismo entre própolis e antimicrobianos tem sido investigado, in vitro, (KROL et al., 1993; SCHELLER et al., 1999; STEPANOVIC et al., 2003) e preparações de própolis com antibióticos e antifúngicos parecem ser de interesse médico em potencial ( STEPANOVIC et al., 2003).

Berretta (2007) avaliou a atividade antimicrobiana in vitro do extrato de própolis e dos géis obtidos, através da técnica de difusão em Agar e também através do método de microdiluição em microplacas contendo caldo de enriquecimento e o revelador trifeniltetrazólio, frente aos microrganismos $S$. aureus, M. luteus e P. aeruginosa. Os resultados demonstraram que o extrato padronizado de própolis (EPP-AF ${ }^{\circledR}$ ) apresentou atividade frente aos microrganismos pesquisados e a concentração inibitória mínima (CIM) para $S$. aureus e $P$. aeruginosa, foram respectivamente, $50 \mathrm{ug} / \mathrm{mL}$ e $200 \mathrm{ug} / \mathrm{mL}$, através da técnica de microdiluição. O produto não apresentou potencial genotóxico nos tratamentos. A pesquisa clínica demonstrou que o gel termorreversível contendo extrato padronizado de própolis $(\mathrm{EPP}-\mathrm{AF})$ a $3,6 \% \mathrm{p} / \mathrm{v}$ de resíduo seco no produto final apresentou tempo de cicatrização de 9,75 $\pm 2,11$ e 10,18 $\pm 2,48$ dias respectivamente.

Preparações de própolis possuem atividade anti-microbiana in vitro, principalmente contra bactérias Gram-positivas (estafilococos e Strepthococci spp.) e bactérias Gram-negativas (E. coli, K. pneumoniae, P. vulgaris e P. aeruginosa), Helicobacter 
pylori, protozoários (T . cruzi), fungos (Candida albicans) e vírus (HIV, vírus Herpes ou vírus influenza) (SFORCIn et al, 2000). Embora o mecanismo de ação do extrato de própolis não tenha sido elucidado, a sua reduzida atividade contra bactérias Gram negativas foi descrita na literatura (PACKER e LUZ, 2007).

\section{E2. Comparação do método da macrodiluição com o método da difusão em} Agar para determinação da atividade antimicrobiana do EPP-AF

O método da macrodiluição em caldo é indicado para avaliar a atividade antimicrobiana de produtos líquidos, como o EPP-AF. No caso de produtos sólidos como as membranas, o método mais indicado é o da difusão em Agar. Portanto, ambos os métodos foram comparados com o intuito de avaliar se eles produziriam resultados semelhantes.

O EPP-AF avaliado no método da difusão em Agar foi diluído de 1/2 a 1/512 utilizando álcool a $70 \%$, pois o mesmo é utilizado na produção do extrato. Os resultados obtidos por este método foram semelhantes aos obtidos pelo método da macrodiluição. Da diluição $1 / 2$ até a diluição 1/32 houve a formação de halos de inibição, sendo que o diâmetro dos halos foi diminuindo conforme a concentração de própolis também diminuía (Figura 15). 


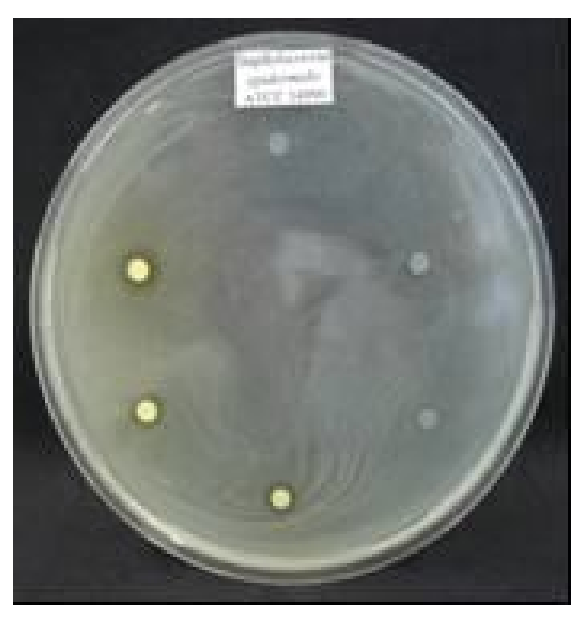

a)

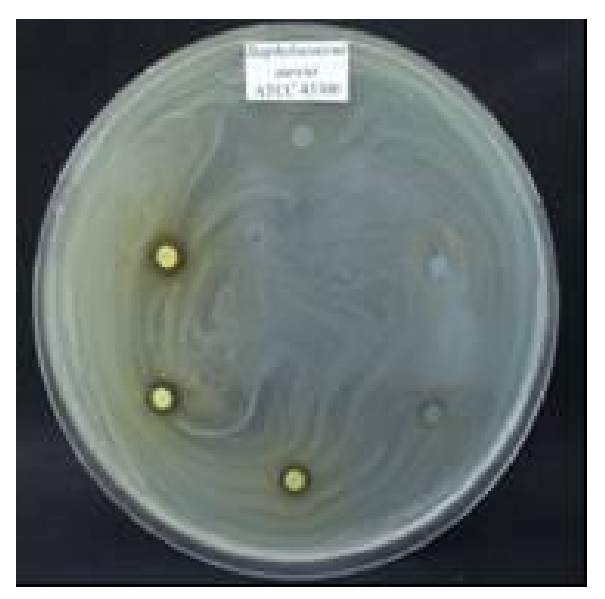

b)

Figura 15. Atividade antimicrobiana das membranas contendo EPP-AF frente a (a) S. aureus ATCC 25923, (b) S. aureus (MRSA) ATCC 43300

A partir da diluição 1/64 não houve a formação de halos de inibição. Isso significou que no método da difusão em Agar, a CBM do EPP-AF frente ao $S$. aureus ATCC 25923 foi de $0,34 \%$ (diluição 1/32), ou seja, o mesmo resultado obtido no método da macrodiluição. Devido à compatibilidade das duas técnicas, pode-se confiar no método da difusão em Agar para avaliar a atividade antimicrobiana das membranas.

\section{E2a. Avaliação da atividade antimicrobiana do EPP-AF}

O EPP-AF apresentou atividade contra $S$. aureus e foi muito relevante, pois essa é a espécie mais patogênica do gênero Staphylococcus. O S. aureus ATCC 43300 é classificado como MRSA, ou seja, é uma cepa multirresistente, a qual apresenta resistência a diversos antibióticos, inclusive aos do grupo dos beta-lactâmicos. Alguns estudos reportaram a reduzida atividade da própolis contra bactérias Gram negativas (PACKER e LUZ, 2007). No 
presente estudo, o EPP-AF não foi estudado quanto a sua atividade contra os microrganismos Gram negativos. (Tabela abaixo).

Tabela 7. Atividade antimicrobiana do extrato padronizado de própolis (EPP-AF) utilizando o método da difusão em Agar

\begin{tabular}{l|c}
\hline Microrganismo & Média dos diâmetros dos halos de inibição (mm) \\
\hline S. aureus ATCC 25923 & 11 \\
S. aureus (MRSA) ATCC 43300 & 10 \\
\hline
\end{tabular}

5E2b. Avaliação da atividade antimicrobiana das membranas

As membranas contendo diferentes concentrações do EPP-AF, obtidos por via úmida, apresentaram atividade contra os dois microrganismos Gram positivos avaliados (tabela 8). 
Tabela 8. Atividade antimicrobiana das membranas contendo extrato padronizado de própolis (EPP-AF) em diferentes concentrações, por meio do método da difusão em Agar.

\begin{tabular}{|c|c|c|c|c|}
\hline \multirow[t]{2}{*}{ Microrganismo } & \multirow[t]{2}{*}{ Processo } & \multicolumn{3}{|c|}{ Concentração do EPP-AF nas membranas } \\
\hline & & $1,2 \%$ & $2,4 \%$ & $3,6 \%$ \\
\hline \multirow{2}{*}{$\begin{array}{l}\text { S. aureus ATCC } \\
25923\end{array}$} & Via Seca & $\mathrm{R}$ & $\mathrm{R}$ & $\mathrm{R}$ \\
\hline & Via Úmida & $\mathrm{S}=8 \mathrm{~mm}$ & $\mathrm{~S}=9 \mathrm{~mm}$ & $\mathrm{~S}=10 \mathrm{~mm}$ \\
\hline \multirow{2}{*}{$\begin{array}{l}\text { S. aureus (MRSA) } \\
\text { ATCC } 43300\end{array}$} & Via Seca & $\mathrm{R}$ & $\mathrm{R}$ & $\mathrm{R}$ \\
\hline & Via Úmida & $\mathrm{S}=7 \mathrm{~mm}$ & $\mathrm{~S}=8 \mathrm{~mm}$ & $\mathrm{~S}=9 \mathrm{~mm}$ \\
\hline
\end{tabular}

S: sensível

$\mathrm{R}$ : resistente

O fato do extrato de própolis ser composto por um complexo de substâncias ativas dificulta a criação de mecanismos de resistência dos microrganismos contra ele. As membranas obtidas por via seca não apresentaram atividade contra nenhum dos microrganismos, provavelmente porque não há incorporação adequada da própolis por este processo, ou ainda, a concentração da própolis nessas membranas foi muito baixa. 


\section{CONCLUSÕES}

Em relação aos objetivos e metodologia utilizada podemos concluir que:

- Foi possível preparar e caracterizar membranas de celulose bacteriana com própolis seca e hidratada;

- O melhor estado da membrana para a formação do compósito foi a fibra com porcentagem de água, presente na sua estrutura;

- Observou-se pela análise termogravimétrica grande perda de massa da CBP entre $250^{\circ} \mathrm{C}$ a $350^{\circ} \mathrm{C}$, sugestivo de degradação da celulose por despolimerização, o que foi confirmado pela curva DSC com evento exotérmico a $350^{\circ} \mathrm{C}$;

- As fibras apresentaram boa estabilidade térmica, próximo a $250^{\circ} \mathrm{C}$, mostrando que o processo de secagem da fibra não influenciou muito em sua estabilidade;

- A análise Termogravimétrica demonstrou que a presença da própolis não alterou significativamente a estabilidade térmica desta membrana;

- Através da análise microbiológica, verificou-se que a concentração mínima de $0,34 \%$ de própolis foi ativo à $S$. aureus, sendo mais sensível a membrana hidratada com própolis.

Desta forma, o compósito de membrana de celulose e própolis, obtido através das duas vias, apresentou propriedades físico-químicas e biológicas próprias e seletivas e estes achados são promissores para futuros trabalhos in vivo e possíveis aplicações médicas. 


\section{REFERÊNCIAS BIBLIOGRÁFICAS}

AMERICAN SOCIETY FOR TESTING AND MATERIALS. D 3878-95: standard terminology for composite materials. West Conshohocken, 1999. 4 p.

ANTOINNETE, C. O. cellulose: the structure slowly unraves. Cellulose, v. 4, p. 173-207, 1997.

ATALLA, R. H. Celluloses. In: ATALLA, R. H. Celluloses. Madison: (s. N.), 1999. cap. 1, p. $529-598$

AZEVEDO, R.V.P.; KOMESU, M.C.; CANDIDO, R.C.; SALVETTI, C.; REZENDE, F.H.C. Cândida sp in the oral cavity with and without lesions: maximal inhibitory dilution of propels and periogard. Revista de Microbiologia, v. 30, p. 335-341, 1999.

BANKOVA, V., BOUDOUROVA-KRASTEVA, G., POPOV, S., SFORCIN, J.M., FUNARI, S.R.C., Seasonal variations in essential oil from Brazilian propolis. Journal of Essential Oil Research, v. 10, 693-696, 1998.

BARUD, H. S. Preparo e caracterização de novos compósitos de celulose bacteriana. 2006. Dissertação de Mestrado (Mestrado em Química) - Instituto de QuímicaUnesp/Araraquara, Araraquara-SP.

BARUD, H. S.; RIBEIRO C. A.; CRESPI, S.; MARTINES, M. A. U.; DEXPERT- GHYS, J.; MARQUES, R. F. C.; MESSADEQ, Y.; RIBEIRO, S. J. L. Thermal characterization of bacterial cellulose-phosphate composite membranes. Journal of Thermal Analysis and Calorimetry, v. 87, n. 3, p. 815-818, 2007.

BARUD, H. S., ASSUNCAO, R. M. N., MARTINES, M. A. U., DEXPERT-GHYS, J., MARQUES, R. F. C., MESSADDEQ, Y., RIBEIRO, S. J. L. Bacterial cellulose- silica organic-inorganic hybrids. J. Sol-Gel Sci. and Tec., v. 46, p.363-367, 2008;

BARUD, H.S.; BARRIOS, C.; REGIANI, T.; MARQUES, R.F.C.; VERELST, M.; CEXPERT-GHYS, J.; MESSADDEQ, Y. AND RIBEIRO, S.J.L. Self-supported silver nanoparticles containing bacterial cellulose membranes. Mat. Sci. \& Eng., C 28, 515, 2008. 
BERRETTA, A. A. Pesquisa pré-clínica e clínica de um gel termorreversível contendo extrato padronizado de própolis (EPP-AF) para a redução do tempo de cicatrização de lesões em pacientes queimados. 2007. 153 f. Tese (Doutorado em Ciências Farmacêuticas) - Faculdade de Ciências Farmacêuticas de Ribeirão Preto, Ribeirão Preto.

BERRETTA, A. A. Desenvolvimento e avaliação de uma forma farmacêutica de liberação sustentada contendo extrato padronizado de própolis para o tratamento de queimaduras. 2003. 78 f. Dissertação (Mestrado em Ciências Farmacêuticas) - Faculdade de Ciências Farmacêuticas de Ribeirão Preto, Ribeirão Preto.

BIELECHI, E. S.; HRYSTYNOWICS, A.; TURKIEWICZ, M.; KALINOWSKA, H. Biotechnoly of Biopolimers. 2005.

BLEDZKI, A. K.; GASSAN, J. Composites reinforced with cellulose based fibres. Progress in Polymer Science, v. 24, p. 221-274, 1999.

BORRELlI, F.,;IZZO, A.A.; MAFFIA, P.; Di CARLO, G.; RUSSO, A.; MAIELlO, F.M.; CAPASSO, F.; MASCOLO, N. Effect of a propels extract and caffeic acid phenethyl ester on formation of aberrant crypt foci and tumors in the rat colon. Fitoterapia 73 (S1), S38 - S43, 2002a.

BORRELlI, F.,;MAFFIA, P.; PINTO, L.; IANARO, A.; RUSSO, A.; CAPASSO, F.; IALENTI, A. Phytochemical compounds involved in the anti-inflammatory effect of propels extract. Fitoterapia 73 (S1), S53-S63, 2002 b.

BROWN, R. M. Jr. Cellulose structure and biosynthesis. Pure Applied Chemistry, v. 71, n. 5, p. 767-775, 1999.

BURDOCK, G. A. Review of the biological properties and toxicity of bee propels. Food and Chemical Toxicology, v. 36, p. 347-363, 1998.

CASTALDO, S.; CAPASSO, F. Propolis, an old remedy used in modern medicine. Fitoterapia, v. 73, p. s1-s6, (Suppl.1), 2002.

CASTRO S.L. Propolis: biological and pharmacological activities. Thera- peutic uses of this bee-product. Annual Review of Biomedical Science 3, p.49-83, 2001. 
CHENG, H. P.; WANG, P. M.; CHEN, J. W,;WU, W. T. Cultivation of acetobacter xylinum for bacterial cellulose production in a modified airlift reactor. Biotecnology applied and Biochemistry, v. 35, p. 125-132, 2002.

COTARELO, M.; CATALAN, P.; SANCHEZ-CARRILLO, C.; MENASALVAS, A.; CERCENADO, E.; TENORIO, A.; BOUZA, E. Cytopath- ic effect inhibition assay for determining the in-vitro sus- ceptibility of herpes simplex virus to antiviral agents. J Antimicrob Chemother 44, p.705-708, 1999.

CZAJA, W. K.; YOUNG, D. J.; KAWECKI, M.; MALCOLM BROWN. The Future Prospects of Microbial Cellulose in Biomedical Applications. Biomacromolecules, v. 8, p. 112, 2007.

DUBEY, V.; SAXENA, C.; SINGH, L.; RAMANA, K.V.; CHAUHAN, R. S. Pervaporation of binary water-ethanol mixtures through bacterial cellulose membrane. Separation and Purification Technology, v. 27, p. 163-171, 2002.

FERNANDES. A. J.; SUGIZAKI, M.F.; FOGO, M.L.; FUNARI, S.R.C.; LOPES, C.A.M. In vitro activity of propolis against bacterial and yeast pathogens isolated from human infections. J. Venom. Anim. Toxins, Botucatu, v.1, n. 2, 1995.

GEORGE, J.; RAMANA, K. V.; SABAPATHY, S. N.; JAGANNATH, J. H.; BAWA, A. S. Characterization of chemically treated bacterial (Acetobacter xylinum) biopolymer: some thermo-mechanical properties. International Journal of Biological Macromolecules, v. 37, p. 189-194, 2005.

GHISALBERTI, E.L. Propolis: a review. Bee World 60, p.59-84, 1979.

HAVSTEEN, B. The biochemistry and medical significance of the flavonoids. Pharmacology and Therapeutics 96, p.67-202, 2002.

HEINZE, T.; LIEBERT, T. Unconventional methods in cellulose functionalization. Progress in Polymer Science, v. 26, p. 1689-1762, 2001.

HIRAI, A.; TSUJI, M.; HORII, F. TEM study of band-like cellulose assemblies produced by Acetobacter xylinum at 4oC. Cellulose, v. 9, p. 105-113, 2002. 
HISANO, C. Desenvolvimento de materiais compósitos baseados em celulose bacteriana produzida por Acetobacter xylinum, 2006. 100 f. Dissertação (Mestrado) - Instituto de Química, Universidade Estadual Paulista, Araraquara, 2006.

IGUCHI, M.; YAMANAKA, S.; BUCHIONO, A. Review: bacterial cellulose: a masterpiece of nature's arts. Journal of Materials Science, v. 35, p. 261-270, 2000.

JONAS, R.; FARAH, L. F. Production and application of microbial cellulose. Polymer degradation and stability, v. 59, p. 101-106, 1998.

KENNEDY,J.F . et al. (Ed). Cellulose and its derivatives: chemistry, biochemistry and applications. Chichester: Ellis Horwood; New York: John Wiley \& sons, p.551, 1985.

KLECHKOVSKAYA, V. V.; BAKLAGINA, Y. G.; STEPINA, N. D.; KHRIPUNOV, A. K.; BUFFAT, P. A.; SUVOROVA, E. I.; ZANAVESKINA, I. S.; TKACHENKO, A. A.; GLADCHENKO, S. V. Structure of cellulose Acetobacter xylinum. Crystallography Reports, v. 48, n. 5, p. 755-762, 2003.

KLEMM, D.; HEUBLEIN, B.; FINK, H. P.; BOHN, A. Cellulose: fascinating biopolymer and sustainable raw material. Polymer Science, v. 44, p. 3358-3393, 2005.

KLEMM, D.; SCHUMANN, D.; UDHARDT, U.; MARSCH, S. Bacterial synthetized cellulose - artificial blood vessels for microsurgery. Progress in Polymer Science, v. 26, p.1561-1603, 2001.

KLEMM, D.; SCHUMANN, D.; KRAMER, F.; HEßLER, N.; HORNUNG, M.; SCHMAUDER, H.; MARSCH, S. Nanocelluloses as innovative polymers in research and application. In: KLEMM, D. Advances in Polymers Science. Berlin Heidelberg: SpringerVerlag. v. 1, p. 49, 2006.

KOYAMA, M.; HELBERT, W.; IMAI, T.; SUGIYAMA, J.; HENRISSAT, B. Parallel-up structure evidences the molecular directionality during biosynthesis of bacterial cellulose. Proceedings of the National Academy of Sciences of the United States of America, v. 94, p. 9091-9095, 1997.

KOO, M. H.; PARK, K. P. Investigação do teor de flavonóides totais da própolis de Apis mellifera do Brasil. Revista Brasileira de Apicultura, p. 8-11, jul./ago. 1996. 
KRAMER, F.; KLEMM, D.; SCHUMANN, D.; HEßLER, N.; WESARG, F.; FRIED, W.; STADERMANN, D. Nanocellulose polymer composites as innovative pool for (bio)material development. Macromolecules Symposia, v. 244, p. 136-148, 2006.

KROL, W.; SCHELLER, S.; SHANI, J.;PIETSZ, G.; CZUBA, Z.Synergistic effect of ethanol extract of propolis and antibiotics in the growth of Staphylococcus aureus. Drug Res. 43,p. 607-609, 1993.

KUZAK, S. G.; HILTZ, J. A.; WAITKUS, P. A. Impact performance of phenolic composites following thermal exposure. Journal of Applied Polymer Science, v. 67, p. 349-361, 1998.

LEE, S.K.; SONG, L.; MATA-GREENWOOD, E.; KELLOFF, G.J.; STEELE, V.E.; PEZZUTO, J.M. Modulation of in vitro biomarkers of the carcinogenic process by chemopreventive agents. Anticancer Research 19 (1A), 35-44, 1999.

MANZANI, D. Determinação da relação das fases $\mathbf{I} \square$ e II $\square$ na celulose produzida pela cepa Glucanoacetobacter xylinus da empresa BIONEXT $\square$. 2004. 38 f. Monografia (Bacharelado em Química) - Instituto de Química, Universidade Estadual Paulista, Araraquara, 2004.

MARTINS, R.S.; PEREIRA, E.S.J.; LIMA JR., S.M.; SENNA, M.I.B.; MESQUITA, R.A.; SANTOS, V.R. Effect of commercial ethanol propolis extract on the in vitro growth of Candida albicans collected from HIV-seropositive and HIV-seronegative Brazilian patients with oral candidiasis. J. Oral Sci., Tokyo, v. 44, n. 1, p. 41-48, 2002.

MARCUCCI, M.C.; RODRIGUEZ, J.; FERRERES, F.; BANKOVA, V.; GROTO, R.; POPOV, S. Chemical composition of Brazilian propolis from São Paulo state. Zeistschrift fur Naturforschung C 53, p.117-119, 1998.

MATTHEWS, F. L.; RAWLINGS, R. D. Composite materials: engineering and science. London: Chapman \& Hall, 1994.

MIRZOEVA, O.K.; GRISHANIN, R.N.; CALDER, P.C. Antimicrobial action of propolis and some of its components: the effects on growth, membrane potential and motility of bacteria. Microbiol Res; p.152:239-46, 1997.

MORMINO,R.P.Evaluation and applications of a rotating disk reactor prodicing bacterial cellulose. 2002. $130 \mathrm{f}$. thesis (Chemical engineering) - Faculty of Renssealer Polytechinic Instituti, New York, 2002. 
NATIONAL COMMITTEE FOR CLINICAL LABORATORY STANDARDS. Methods for determining bactericidal activity of antimicrobial agents; Approved guideline (M26-A), Vol. 19 (18). Wayne, PA: NCCLS; 2000.

NATIONAL COMMITTEE FOR CLINICAL LABORATORY STANDARDS. Methods for dilution antimicrobial susceptibility tests for bacteria that grow aerobically; Approved guideline (M7-A5), Vol. 20 (2). Wayne, PA: NCCLS; 2000.

NIEVA MORENO, M.I.; ISLA, M.I.; CUDMANI, N.G.; VATTUONE, M.A.; SAMPIETRO, A.R. Screening of antibacterial activity of Amaicha del Valle (Tucuma' n, Argentina) propolis. J. Ethno- pharmacol. 68, p. 97-102, 1999.

NOMURA, M.; KAJI, A.; MA, W.; MIYAMOTO, K.; DONG, Z. Suppression of cell transformation and induction of apoptosis by caffeic acid phenethyl ester. Molecular Carcinogenesis. 31 (2), p.83-89, 2001.

O'SULliVAN, A. Cellulose: the structure slowly unravels. Cellulose, v. 4, p. 173-207, 1997.

PACKER, J.F.; LUZ, M.M.S. Método para avaliação e pesquisa da atividade antimicrobiana de produtos de origem natural. Rev Bras Farmacogn 17: p.102-107, 2007.

PANDEY, L. K.; SAXENA, C.; DUBEY, V. Studies on pervaporative characteristics of bacterial cellulose membrane. Separation Purification Technology, v. 42, p. 213-218, 2005.

PAIVA, J. M. F.; FROLLINI, E. Sugarcane bagasse reinforced phenolic and lignophenolic composites. Journal of Applied Polymer Science, v. 83, p. 880-888, 2002.

PÉREZ, S.; MACKIE, B. Structure and morphology of cellulose, 2001. Disponível em: $<$ http://www.cermav.cnrs.fr/glyco3d/index.php>. Acesso em: 05 ago. 2006.

PEPELJNJAK, S. ; KOSALEC, I. Galangin expresses bacte- ricidal activity against multipleresistant bacteria: MRSA, Enterococcus spp. and Pseudomonas aeruginosa. FEMS Microbiol Lett 240, p.111-116, 2004.. 
PINTO, E. R. P. Estudo do Sistema Celulose Bacteriana-Poliuretana para a produção de novos compósitos. 2007. 172f. Dissertação (Mestrado) - Instituto de Química, Universidade Estadual Paulista, Araraquara, 2007.

PRINCI, E.; VICINI, S.; PEDEMONTE, E.; ARRIGHI, A.; MCEWEN, I. Thermal characterization of cellulose based materials investigation of water content. Journal of Thermal Analysis and Calorimetry, v. 80, p. 369-373, 2005.

RECOUVREX, D. O. S. Produção de cellulose bacteriana: identificação do operon bcs e produção de biofilme celulosico por Chromobacterium violaceum. 2004. $124 \mathrm{f}$. Dissertação (Mestrado em Engenharia Quimica) - Universidad federal de Santa Catarina, 2004.

REIS C.M.F.; CARVALHO, J.C.T.; CAPUTO, L.R.G.; PATRACIO, K.C.M.; BARBOSA, M.V.J.; CHIEFF, A.L.; BASTOS, J.K. Atividade Antiinflamatória, Antiúlcera Gástrica e Toxicidade Subcrôncia do Extrato Etanólico de Pró polis. Brazilian Journal of Pharmacognosy 10,p. 43-52, 2000.

ROSSI, A., LIGRESTI, A., LONGO, R., RUSOO, A., BORRELli, F., SAUTEBIN, L. The inhibitory effect of propolis and caffeic acid phenethyl ester on cyclooxygenase activity in J774 macrophages. Phytomedicine 9 (6), p. 530-535, 2002.

RUSSO, A.; LONGO, R.; VANELLA, A. Antioxidant activity of propels: role of caffeic acid phenethyl ester and galangin. Fitoterapia, v. 73, p. S21-S29, (Suppl. 1), 2002.

SANTOS, F. A. et al. Brazilian propolis: physicochemical properties, plant origin and antibacterial activy on periodontopathogens. Phytotherapy Research, v. 17, p. 285-289, 2003.

SAWYER, L. C.; GRUBB, D. T. Polymer microscopy. 2nd ed. London: Chapman \&Hall, 1996. 399 p.

SCAZZOCHIO, F., D’AURIA, F.D., ALESSANDRINI, D., PANTANELLA, F. Multifactorial aspects of antimicrobial activity of propolis. Microbiol Res 161, p.327-333, 2006.

SCHELLER, S., DWORKICZAK, S., WALDEMAR-KLIMMEK, K., RAJCA, M., 
TOMCZYK, A., SHANI, J. Synergism between ethanolic extract of propolis (EEP) and antituberculosis drugs on growth of mycobacteria. Z Naturforsch; 54, p. 549-553, 1999.

SFORCIN, J.M., FERNANDES JR. A., LOPES, C.A.M., BANKOVA, V., FUNARI, S.R.C. Seasonal effect on Brazilian propolis antibacterial activity. J. Ethnopharmacol., Lausanne, v. 73, p. 243-249, 2000.

SFORCIN, J.M.; NOVELLI, E.L.B.; FUNARI, S.R.C. Seasonal effect of Brazilian propolis on seric biochemical variables. J. Venom. Toxins, Botucatu, v. 8, n. 2, p. 244-254, 2002.

SILVA, R. V. Compósito de resina poliuretano derivada de óleo de mamona e fibras vegetais. 2003. 157 f. Tese (Doutorado) - Escola de Engenharia de São Carlos, Universidade de São Paulo, São Carlos, 2003.

SILVESTRE FILHO, G. D. Comportamento mecânico do poliuretano derivado de óleo de mamona reforçado por fibra de $\mathbf{C}$ : contribuição para o projeto de hastes de implante de quadril. 2001. 156 f. Dissertação (Mestrado em Engenharia) - Departamento de Engenharia Mecânica, Universidade de São Paulo, São Carlos, 2001.

SJOSTROOM, E. Wood chemistry: fundamental and applications. Cellulose. New York: Academic Press, p. 1683, 1981.

STEPANOVIC, S., ANTIC, N., DAKIC, I., SVABIC-VLAVOHIC, M. In vitro antimicrobial activity of propolis and synergism between propolis and antimicrobial drugs. Microbiol. Res.; 158: 353-7, 2003.

STEINBÜCHEL, A.; DOI, Y. (Ed.). Biotechnology of biopolymers. Weinheim: WILEYVCH Verlag, p. 381-435, 2005.

TEIXEIRA, E.W., NEGRI, G., MEIRA, R.M.S.A., MESSAGE, D., SALATINO, A.,. Plant origin of green propolis: bee behavior, plant anatomy and chemistry. Evidence Based Complementary Alternative Medicine 2, 85-92, 2005.

VANDERHART, D. L.; ATALLA, R. H. The structures of cellulose: characterization of the solid states. Washington: American Chemical Society, 1987. p. 88-118. (ACS Symposium, v. 340). 
WADA, M.; SUGIYAMA, J.; OKANO, T. Native celluloses on the basis of two crystalline phase (I $\alpha / \mathrm{I} \square)$ system. Journal of Applied Polymer Science, v. 49, n. 8, p. 1491-1496, 1993.

WILLIANS, W. C.; CANNON, E. R. Alternative environmental roles for cellulose produced by Acetobacter xylinum. Applied and Environmental Microbiology, v. 55, p. 2448-2452, 1989. 